NBER WORKING PAPER SERIES

\title{
IS THE MELTING POT STILL HOT? EXPLAINING THE RESURGENCE OF IMMIGRANT SEGREGATION
}

\author{
David M. Cutler \\ Edward L. Glaeser \\ Jacob L. Vigdor \\ Working Paper 11295 \\ http://www.nber.org/papers/w11295 \\ NATIONAL BUREAU OF ECONOMIC RESEARCH \\ 1050 Massachusetts Avenue \\ Cambridge, MA 02138 \\ April 2005
}

\begin{abstract}
We are grateful to Audrey Beck for outstanding research assistance and to the Russell Sage Foundation for financial support. We also thank seminar participants in the Wharton Real Estate Group and at the 2003 North American Regional Science Council meetings for valuable comments on earlier versions of this paper. This paper reports the results of research and analysis undertaken while the corresponding author was a research affiliate at the Center for Economic Studies at the U.S. Census Bureau. It has undergone a Census Bureau review more limited in scope than that given to official Census Bureau publications. Research results and conclusions expressed are those of the authors and do not necessarily indicate concurrence by the Census Bureau. It has been screened to insure that no confidential information is revealed. The segregation indices used in this paper are available on our website: http://trinity.aas.duke.edu/ jvigdor/segregation. The views expressed herein are those of the author(s) and do not necessarily reflect the views of the National Bureau of Economic Research.
\end{abstract}

(C2005 by David M. Cutler, Edward L. Glaeser, and Jacob L. Vigdor. All rights reserved. Short sections of text, not to exceed two paragraphs, may be quoted without explicit permission provided that full credit, including () notice, is given to the source. 
Is the Melting Pot Still Hot? Explaining the Resurgence of Immigrant Segregation

David M. Cutler, Edward L. Glaeser, and Jacob L. Vigdor

NBER Working Paper No. 11295

April 2005

JEL No. J1, N3, R0

\begin{abstract}
$\underline{\text { ABSTRACT }}$
This paper uses decennial Census data to examine trends in immigrant segregation in the United States between 1910 and 2000. Immigrant segregation declined in the first half of the century, but has been rising over the past few decades. Analysis of restricted access 1990 Census microdata suggests that this rise would be even more striking if the native-born children of immigrants could be consistently excluded from the analysis. We analyze longitudinal variation in immigrant segregation, as well as housing price patterns across metropolitan areas, to test four hypotheses of immigrant segregation. Immigration itself has surged in recent decades, but the tendency for newly arrived immigrants to be younger and of lower socioeconomic status explains very little of the recent rise in immigrant segregation. We also find little evidence of increased nativism in the housing market. Evidence instead points to changes in urban form, manifested in particular as native-driven suburbanization and the decline of public transit as a transportation mode, as a central explanation for the new immigrant segregation.
\end{abstract}

David M. Cutler

Department of Economics

Harvard University

Cambridge, MA 02138

and NBER

dcutler@harvard.edu

Edward L. Glaeser

Department of Economics

315A Littauer Center

Harvard University

Cambridge, MA 02138

and NBER

eglaeser@harvard.edu
Jacob L. Vigdor

Terry Sanford Institute of Public Policy

Duke University

Durham, NC 27708

and NBER

jacob.vigdor@duke.edu 


\section{Introduction}

Since 1960, the average foreign born resident of the United States has experienced steadily increasing levels of segregation from the population at large. As Figure 1 shows, mean levels of the two classic measures of segregation - dissimilarity and isolation indices - are considerably higher today relative to a generation ago. These general trends toward increasing segregation mask a remarkable degree of variation in the experiences of different ethnic groups and trends in different parts of the country. While segregation has increased for many individual ethnic groups, it has declined for some, and has remained relatively constant for some of the nation's fastest growing immigrant groups, including Mexicans. Few if any immigrant groups, however, have experienced the wholesale decline in segregation witnessed by African Americans during the same time period (Cutler, Glaeser, and Vigdor 1999).

Why has immigrant segregation increased even as racial segregation has declined? Are there systematic factors that can explain the disparate experiences of different ethnic groups? In this paper, we use variation in segregation over time, across cities, and across ethnic groups to evaluate four theories of immigrant segregation. The first theory argues that changes in measured immigrant segregation over time are driven largely by the non-heritability of immigrant status and fluctuations in flows of new migrants into the host country. The second theory asserts that immigrants cluster together when they have cultural characteristics in common with each other (such as language) that differ from the characteristics of the population as a whole. Immigrant groups with stronger ties to American culture, or those that have undergone greater assimilation, should experience less segregation according to this theory.

Two other theories focus on factors that are external to immigrants themselves. The third 
theory posits that nativism, or other forms of discrimination against immigrants, drives immigrant segregation. Natives might either be willing to pay to avoid immigrants (decentralized discrimination) or may be able to effectively restrict immigrant location choices (centralized discrimination). The fourth theory focuses on the changing nature of the American city, in particular the rise of car-based living on the urban periphery. Economic segregation increased in the 1970s and 1980s (Jargowsky, 1997), possibly because of class differences in transportation modes (Glaeser, Kahn and Rappaport 2001). Disparities in economic class between immigrants and natives, and their changing implications regarding the importance of accessibility to transportation and employment, may explain some portion of the rise in immigrant segregation.

In Section II of this paper, we introduce our data on immigrant segregation in the United States over the twentieth century. Using data from the Census enumerations of 1910, 1920, 1940, 1950, 1970, 1980, 1990, and 2000, we compute segregation indices for dozens of immigrant groups across hundreds of cities and metropolitan statistical areas (MSAs).The data reveal that immigrant segregation began the twentieth century at relatively high levels, then declined as Federal restrictions and other forces stemmed the tide of immigration after 1920. Over the latter half of the century, as immigrants born in Latin America and Asia began to enter the country in large numbers, segregation rose once again. By one measure, immigrant segregation stabilized during the 1990s, but the isolation of immigrants from the general population continued to increase.

In Section III, we use restricted-access Census microdata to compute alternative segregation indices designed to circumvent measurement issues related to the non-heritability of immigrants status. The alternative indices suggest that self-integration bias has the greatest impact on segregation indices of the most isolated groups. Thus, the time series evidence presented in 
Figure 1 would most likely be even more dramatic if we were able to apply this correction using all years of our data.

In Section IV of the paper, we discuss our three remaining theories and describe our methods of distinguishing the relative importance of each. In Section V, we use city and immigrant group characteristics to explain longitudinal variation in segregation levels. We find significant evidence in favor of the cultural difference hypothesis. Immigrants with more experience in the US and those from countries where the predominant language is more linguistically similar to English tend to be less segregated. Controlling for these factors explains only a relatively small portion of the overall increase in immigrant segregation, however. We also find evidence supporting the urban form hypothesis: the strongest increases in segregation since 1970 have occurred in metropolitan areas with a heavy reliance on public transit. The segregating influence of public transportation has increased substantially over the past thirty years, as the market share of that commuting mode has declined.

In Section VI, we follow Cutler, Glaeser and Vigdor (1999) and look at housing prices to test the various theories of immigrant segregation. We find that immigrants paid a premium for housing in segregated markets as recently as 1970, but that this premium had disappeared by 2000. The most likely explanation for this pattern is that immigrants now tend to occupy neighborhoods that have fallen out of favor with natives. Indeed, in 2000 over $40 \%$ of all foreign-born individuals lived in a metropolitan area where immigrant location patterns bore a closer resemblance to the native residential distribution in 1970 than in any subsequent Census enumeration. There is at least some evidence that the presence of immigrants has caused natives to lower their valuation of these neighborhoods (Saiz and Wachter, 2004). 
Section VII concludes.

\section{Measuring segregation}

There are numerous ways of measuring residential segregation within a population. In this paper, as in our previous work (Cutler, Glaeser and Vigdor 1999; Glaeser and Vigdor 2003) we focus on two measures in particular. The indexes of dissimilarity and isolation have many antecedents in the sociological literature (Bell 1954; Duncan and Duncan 1955; Taeuber and Taeuber 1965), and unlike many other segregation indices they require no information on the geographical location and land area of neighborhood units (Massey and Denton 1988). These unrestrictive data requirements are advantageous, since we have little information on the geographic arrangement of neighborhoods within a city in the earlier years of our panel.

The dissimilarity index is one of the most commonly used measures of segregation. It is calculated by dividing a city or metropolitan area into neighborhoods, indexed $i$, and using the formula in equation (1):

(1) Dissimilarity Index $1 \frac{1}{\mid \text { group }_{i}}-\frac{\text { non- }_{\text {tol }} \text { group }_{i}}{\text { non-group }_{\text {total }}} \mid$

where group $_{i}$ denotes the number of relevant immigrant group members living in neighborhood $i$, group $_{\text {total }}$ the number living in the entire city or metropolitan area, and non-group $i$ and non-group total $_{\text {tol }}$ are similarly defined for residents not belonging to the group in question. ${ }^{1}$ The dissimilarity index

\footnotetext{
${ }^{1}$ Segregation indices require us to operationalize the concept of "neighborhood." Our definition of neighborhood is driven largely by data availability. Prior to 1940, the Census Bureau reports population statistics, including a count of the foreign born population by country of origin, at the city ward level. Wards are political subdivisions of cities which range widely in shape and size across cities. For this reason, some caution is warranted when interpreting segregation indices based on ward data (Cutler, Glaeser and Vigdor, 1999). Beginning in 1940, we use census tracts as our neighborhood construct. Tracts are designed to be of relatively constant size, each containing roughly 4,000 residents, with boundaries usually determined by large roads, railroad tracks, or natural features.

In almost all cases, tracts are smaller geographical units than wards. For this reason, segregation measured at the ward level tends to be lower than segregation measured at the tract level (Cutler, Glaeser and Vigdor 1999). In
} 
takes on a value of zero when each neighborhood contains a constant proportion of group members, and a value of one when group members never share neighborhoods with non-group members. Intermediate values can be interpreted as the share of group members that would have to switch neighborhoods in order to achieve an even distribution across the city or metropolitan area.

The isolation index measures the degree of exposure that immigrants have to other members of their group, correcting for the fact that groups forming a larger share of the population have naturally higher exposure rates. We calculate the index with the following formula:

(2) Isolation Index $=\stackrel{i}{ }$

$$
\left(\sqrt{\frac{\text { group }_{i}}{\text { group }_{\text {total }}}} \times \frac{\text { group }_{i}}{\text { population }_{i}}-\frac{\text { group }_{\text {total }}}{\text { population }_{\text {total }}}\right.
$$

$$
\min \left(1, \frac{\text { group }_{\text {total }}}{\text { population }_{\text {smallest }}}\right)-\frac{\text { group }_{\text {total }}}{\text { population }_{\text {total }}}
$$

where group $_{i}$ and group $_{\text {total }}$ are defined as above, population $_{i}$ and population total $_{\text {represent the overall }}$ population in tract $i$ and the entire city or metropolitan area, and population smallest $_{\text {is }}$ the population of the neighborhood with the fewest residents in the city or metropolitan area. The numerator of this formula is the difference between the neighborhood group share experienced by the "average" group member and the share that would be expected if the group were spread evenly across all neighborhoods. The denominator scales the numerator to have a theoretical range between zero and one. An index value of zero implies that the immigrant group is spread evenly across previous work, using data on black-white segregation in 1940, when both ward and tract data were available for many cities, we determined that the discrepancy between ward- and tract-level segregation was approximately 15 percentage points for both the dissimilarity and isolation indices. While it is unclear whether similar adjustment factors would apply in the case of immigrant segregation, the reader is encouraged to keep this factor in mind while reviewing the results below. 
neighborhoods. A value of one occurs when group members are concentrated in neighborhoods where all residents belong to the group. ${ }^{2}$

\section{Trends in Immigrant Segregation}

Our most basic summary information on immigrant segregation in the twentieth century is summarized in Table 1 and Figure 1. Both the table and figure show weighted average segregation levels, with weights equal to the size of an immigrant community. ${ }^{3}$ Indices of dissimilarity and isolation followed generally similar paths, falling in the early part of the century, then rising in the latter portion. Isolation began at a relatively elevated level and fell between 1920 and 1950 even as dissimilarity began its rise. ${ }^{4}$ Table 1 indicates that this pattern mirrors trends in the overall size of the immigrant population, which also reached a relative minimum in 1950 . Depending on the index

\footnotetext{
${ }^{2}$ Before proceeding with interpretation of these trends, it is important to note three limitations with our time series. First, as noted above, our definition of a neighborhood changes between 1920 and 1940. This complicates any comparison of segregation levels before 1940 with those experienced afterwards. Second, the definition of a city changes over time as well. Beginning in 1970, our data pertain to metropolitan statistical areas (MSAs) rather than cities. This change may be responsible for some portion of differences in segregation levels between 1950 and 1970. Finally, our segregation data for 1980 are incomplete. To compute segregation indices in 1980 and later years it is necessary to consult Census Summary File 4A. We attempted, unsuccessfully, to acquire a complete version of this file from the Census Bureau. Failing in this attempt, we collected data from a number of different sources for a total of 32 states and the District of Columbia. While the states included in our collection cover the vast majority of the immigrant and native population, we are unable to compute indices for immigrant communities in Connecticut, Colorado, and several other smaller states. Finally, in 2000, the Census Bureau stopped tabulating immigrants by country of origin by tract in public use data. Our 2000 indices are based on restricted-access Census microdata, the same underlying source used to produce public use files.

${ }^{3}$ We define an immigrant community as a group of at least 1,000 individuals born in the same country residing in the same city. The values shown can thus be interpreted as the segregation experienced by the "average" immigrant in each year.

${ }^{4}$ The decline between 1920 and 1940 is especially noteworthy since the transition from wards to tracts should lead to a natural increase in our index.
} 
used, immigrant segregation levels in 2000 either match the highest levels in recorded history (dissimilarity) or stand at levels not seen in 70 years (isolation). ${ }^{5}$

Table 1 presents summary statistics for a selection of major immigrant groups in 1910 and 2000. In 1910, the largest immigrant groups represented European countries such as the four listed in the table. Immigrant groups from Northern and Western Europe, represented by Germany and Ireland in this table, experienced less segregation than the average immigrant in 1910, perhaps because of their more lengthy tenure in the country. Immigrants from Southern and Eastern Europe, such as Italians and Russians, were generally more recent arrivals and experienced greater segregation. Both Russian and Italian immigrants experienced average dissimilarity levels on the order of 0.5 and isolation levels around 0.1 .

Ninety years later, segregation levels experienced by a new cohort of recent immigrants were remarkably similar to those observed in 1910. By the end of the century, the largest immigrant groups in the United States hailed from Latin American and Asian countries. Table 1 shows summary information for the six largest immigrant groups by country of origin: Mexicans, Filipinos, Germans, Vietnamese, Indians, and Chinese. With the exception of the more modestly segregated German group, these immigrant groups experienced average dissimilarity levels between 0.5 and 0.6, remarkably similar to those of the "newer" immigrant groups in 1910. The highest isolation levels, for Mexican and Chinese immigrants, approach the levels of Russian and Italian immigrants in 1910 .

\footnotetext{
${ }^{5}$ The transition from ward to tract data, and from city to MSA aggregation, imply that caution should be used in the interpretation of differences between early (1910-20) and later (1970-1990) parts of the century. Trends within these time periods are not subject to similar caveats. The relative stability of dissimilarity between 1990 and 2000 in some respects echoes Jargowsky's (2003) findings that economic segregation declined during the 1990s. As we will see later, some of the same forces identified as potential drivers of economic segregation show a relationship with immigrant segregation.
} 
These overall trends in segregation mask considerable variation across immigrant groups. Figures 2 through 7 display long-term trends in dissimilarity and isolation levels for three sets of immigrant groups. Not only do the individual groups vary in their long term experiences, but individual groups' trends vary depending on the segregation index examined. Figures 2 and 4, which track the dissimilarity of "old" and "new" European immigrant groups, mirror the overall trend towards increasing dissimilarity in the later $20^{\text {th }}$ century. Isolation, on the other hand, has been decreasing for most of these groups, as seen in figures 3 and 5. As seen in Table 1, the older immigrant groups of Northern and Western Europe have historically had lower segregation levels than those of Southern and Eastern Europe; this gap appears to be closing in recent data.

Omissions in Census reporting make it difficult to construct historical time series on the segregation of Asian and Latin American immigrant groups. Figures 6 and 7 summarize the available dissimilarity and isolation indices for these groups. The newest immigrant groups generally experience high levels of segregation. For the groups shown here, however, dissimilarity has been either constant or decreasing in recent years. Isolation, by contrast, has remained steady or risen for each group in each decade since 1970.

Analyzing the graphs as a group, several notable patterns appear. The considerable rise in overall average dissimilarity between 1950 and 1990 is not replicated in the time pattern for any individual group. While dissimilarity increased for many groups between 1950 and 1970, the general picture between 1970 and 1990 is one of stasis or decline for most immigrant groups, particularly the "newest" groups plotted in the last figures. The overall stability in immigrant dissimilarity in the 1990s is masks notable increases for many European groups, coupled with stable or declining dissimilarity for the "newest" groups. Similarly, the overall rise in isolation between 
1970 and 2000 is not perfectly replicated by any individual group. Overall levels of immigrant segregation are rising largely because the composition of the immigrant population is shifting towards the more-segregated "newest" groups.

Another intriguing pattern is the tendency for dissimilarity and isolation indices to move in opposite directions over time. In the last half of the century, most European immigrant groups experienced increases in dissimilarity and decreases in isolation simultaneously. That is to say, these groups witnessed an increase in distance between their neighborhoods and those occupied by nongroup members, but within their own neighborhoods their degree of concentration declined. For the newest immigrant groups, those experiencing the most rapid population growth, the pattern is reversed. For these groups, dissimilarity levels are declining or stable, while isolation levels have been increasing. The newest immigrants are appearing in an ever-increasing number of neighborhoods, but those neighborhoods are becoming increasingly concentrated. These observations are consistent with groups experiencing rapid growth, but it should be noted that even for some of these groups rapid growth has brought very little change in segregation levels in the past twenty years.

These clues that dissimilarity and isolation capture distinct phenomena and are influenced by different factors will be corroborated by further evidence in Section V below. In general, highly dissimilar ethnic communities tend to be small in absolute size, while highly isolated communities tend to be very large. 


\section{Do Immigrants Integrate Themselves by Having Children?}

One important distinction between the segregation of racial and immigrant groups is that race is a heritable trait while immigrant status is not. Thus even without residential mobility, immigrant groups will tend to appear more integrated over time as they bear native children. It is possible, for example, that the relatively low amounts of immigrant segregation in the mid-20th century can be attributed to a relatively high native-born-child to immigrant ratio. While we lack the data necessary to evaluate the extent of "childbearing bias" for most of the sample, our access to restricted use Census microdata for 1990 enable us to perform a cross-sectional analysis.

Restricted-access microdata, which enable us to observe living arrangements and tract-level geographic identification for a one-in-six sample of US households, permit the computation of alternative dissimilarity and isolation indices for each immigrant community in our sample. The alternative indices vary from the original version in their definition of the "other" group - all nongroup members in the same metropolitan area. The first set of alternative indices measures the segregation of immigrant group members from native-born individuals. These indices, denoted $D_{N}$ and $I_{N}$ for dissimilarity and isolation, will be higher than the original versions to the extent that immigrant groups locate near one another in cities. The second set of alternative indices measures the segregation of immigrant group members from a subset of natives: those living in households where no immigrants live. These indices will be denoted $D_{\mathrm{NOH}}$ and $I_{\mathrm{NOH}}$ for dissimilarity and isolation, with the $\mathrm{NOH}$ standing for "Native-only households." Natives disqualified from this more restrictive definition will consist largely of immigrants' own native-born children and other nativeborn housemates. 
Table 2 presents summary statistics and correlations for the original dissimilarity and isolation indices computed with 1990 public-use summary data, as well as a substitute version computed with the restricted-access microdata and the two alternative indices described above. In theory, the original indices based on public-use data and restricted-access microdata should be identical, since the latter is the sole source of the former. As Table 2 shows, however, the two indices differ slightly in means and are imperfectly correlated, albeit at the $98 \%$ level or better. Divergences between the two indices can be attributed to Census imputation and weighting procedures, which influence the public-use summary data but have not been applied to the restrictedaccess microdata. ${ }^{6}$

The two alternative indices are also highly yet imperfectly correlated with the indices that follow the original definition. The impact of changing definitions on measured dissimilarity is generally quite small; comparing indices based on restricted-access data reveal that $D_{N O H}$ is correlated at 0.993 with the original version of the index. Figure 8 shows this relationship graphically. Among the roughly 2,000 points shown in this scatterplot, only a few dozen can be identified at any significant distance from the 45-degree line. It should be noted, however, that the mass of data points shown on the graph is clustered slightly above the 45-degree line, suggesting that immigrant childbearing has a consistent but small depressing effect on dissimilarity measures. The weighted mean difference between the original dissimilarity index and $D_{\mathrm{NOH}}$, using weights equal to the number of immigrants in the group, is 0.027 . A bivariate regression reveals that the slope

\footnotetext{
${ }^{6}$ As noted previously, our 2000 segregation indices are constructed with restricted-access Census microdata. On the basis of evidence in Table 2, we expect these indices to be strongly, though not perfectly, correlated with indices that would have been obtained from public-use data.
} 
coefficient in this relationship is not distinguishable from 1 , but the intercept term is significantly greater than zero. ${ }^{7}$

Correlation coefficients between isolation indices computed with different formulae are somewhat lower. The correlation between the restricted-access data-based index using the original formula and $I_{N O H}$ is 0.945 . Figure 9 shows this relationship graphically. Virtually every data point in this plot lies above the 45-degree line, and the divergence from this line increases from left to right. The implication of this graph is that immigrant childbearing produces a noticeable decline in isolation levels, particularly among those groups experiencing high levels of isolation. A regression line plotted to fit the data in Figure 9 would feature an intercept term indistinguishable from zero and a slope coefficient of roughly 1.6. This suggests that immigrants' tendency to share households with their own children and other natives leads to a significant understatement of isolation levels among the most segregated groups. ${ }^{8}$ The weighted mean difference between the original isolation index and $I_{N O H}$ is 0.052 . The average isolation of immigrants from households containing only natives is almost twice as high as immigrant isolation from all other individuals.

Unfortunately, the data required to perform this exercise are not available for earlier years. We can, however, use our 1990 results to make predictions about what alternative index values would have been in earlier years. Specifically, we compute the gap between alternative and original measures of segregation, $D_{\mathrm{NOH}^{-}}-D$ and $I_{\mathrm{NOH}^{-}}-I$, and regress those values on country of origin fixed

\footnotetext{
${ }^{7}$ Some part of this relationship can be attributed to the fact that the original definition of the dissimilarity index masks situations where immigrants share neighborhoods with immigrants of different national origin groups. Regressions of the immigrants-vs-natives index on the original version, and of the immigrants-vs-natives-in-nativeonly-households index on the immigrants-vs-natives index reveals that no more than $20 \%$ of the divergence shown in Figure 5 can be attributed to immigrant group colocation.

${ }^{8}$ Further regression decomposition reveals that about $1 / 3$ of this $60 \%$ understatement can be attributed to the tendency for immigrant groups to co-locate. The majority of the effect can be attributed to immigrant childbearing.
} 
effects, city fixed effects, and immigrant group/year/city specific characteristics derived from Census and IPUMS data samples for $1990 .{ }^{9}$ We then make out-of-sample predictions based on immigrant data from earlier years. The results of this exercise suggest that the most severe childbearing bias in immigrant segregation indices occurs in periods of time when measured segregation levels are high: the early and late parts of the twentieth century. Thus, concerns that the dip in immigrant segregation can be attributed to childbearing bias are unfounded - in fact, our rough attempt to eliminate childbearing bias suggest that the long-term dynamics in immigrant segregation are even more extreme than they appear.

\section{The Causes of Segregation}

In this section, we discuss three potential explanations for the rise in immigrant segregation. We will divide our explanations into three broad categories: (1) cultural distance, (2) discrimination and (3) urban form. The first category emphasizes changes within the immigrant community. The second two categories emphasize external changes.

\section{Culture and Assimilation}

Perhaps the most common theory of immigrant ghettos is that these concentrations occur because immigrants want to live near people with similar tastes and who speak the same language. Because sharing preferences and communication tools is desirable, immigrants will systematically outbid natives for housing in neighborhoods with high same-group concentrations. Immigrants from

\footnotetext{
${ }^{9}$ These characteristics include immigrant group size, mean immigrant age, and mean immigrant occupation score. Observations in this regression are weighted by the sample size used to compute the immigrant group/year/city specific characteristics. The regressions reveal that larger immigrant groups tend to have higher gaps between original and alternative indices, and that higher SES groups (as measured by the occupation score) have higher gaps between original and alternative dissimilarity indices.
} 
countries that are more culturally different from the U.S. should display the greatest tendency to follow this pattern. This theory also predicts that as some assimilation occurs even for those immigrants who live in segregated communities, we should expect to see that immigrants who have lived in the U.S. longer will live in less segregated communities.

We will focus on whether segregation across groups is related to the degree of cultural distance from the United States and to the length of time that group members have spent in the country. We use two measures of the cultural distance between a country of origin and the United States. First we consider linguistic difference. Using a well-established categorization of language families (Comrie, Matthews, and Polinsky 1996), we sort immigrant groups into those from English speaking countries, those from countries speaking other Germanic languages, those from countries speaking Indo-European languages outside the Germanic branch, and those from countries speaking non-Indo-European languages. Second, we consider difference in the degree of development as measured by origin country GDP. This theory suggests that the degree of cultural sharing is related to similarity in the degree of economic development. We can also test the importance of socioeconomic status at a more micro level by controlling for a measure of the skill content of immigrants' occupations by country of origin, destination city, and year.

If segregation is driven by a desire for immigrants to live in close proximity to other members of their ethnic group, the density of the group in the population should be an important determinant of segregation levels. Groups forming a high proportion of the population do not need to cluster in certain neighborhoods to take advantage of proximity to other members. Thus, controlling for city size larger immigrant groups should experience less isolation. Controlling for group share, on the other hand, immigrants in larger cities may exhibit a greater tendency to cluster, 
since physical distances between members will be greater in larger cities.

A final strategy for testing the culture and assimilation hypothesis will focus on the link between immigrant segregation and the prices that immigrants pay for housing across metropolitan areas. If immigrants place a positive value on living in an enclave community, we should observe that immigrants pay premiums to live in a segregated community. Relatively unassimilated immigrants should place the highest value on exposure to members of their own group; we therefore expect newly arrived immigrants to pay the highest premium for housing.

\section{Discrimination}

A second theory of rising segregation of immigrants is that these immigrants have become targets of increasingly more virulent nativism. This change may be attributable in part to racial distinctions between natives and the most rapidly growing immigrant groups. There are several natural ways to test this theory. A simple test would examine whether immigrant groups belonging to different racial categories experience significantly higher segregation controlling for other characteristics. It is reasonable to expect that nativism increases in the density of the immigrant population, in which case group share would be a positive predictor of segregation. This empirical test stands in direct contrast to the culture and assimilation hypothesis. Finally, following the methodology of Kain and Quigley (1975) and Cutler, Glaeser and Vigdor (1999), we can examine the link between segregation and the prices that immigrants pay for housing. If discrimination against immigrants takes on a centralized form, whereby natives impose restrictions on immigrant location choices, we expect immigrants to pay a premium for housing. Unlike the preceding hypothesis, we would expect such a discrimination-related premium to apply to immigrants equally regardless of their degree of assimilation or expectations regarding length of stay in the host country. 
If discrimination against immigrants is decentralized, we would expect natives to pay a premium for housing in communities with higher degrees of immigrant segregation. As detailed below, native premia for housing in segregated areas is also consistent with the hypothesis that immigrants occupy neighborhoods that have fallen out of favor with natives. To distinguish these explanations, we will test whether immigrant discounts for housing are particularly acute for immigrants who belong to particular racial groups.

\section{Urban Form}

A final hypothesis is that immigrant segregation is getting worse because of changes in urban form and in particular the rise of low-density suburban residence and employment. In cities where public transit is a feasible commuting alternative, the location decisions of socioeconomically marginalized groups, such as immigrants, may be highly sensitive to proximity to the transit grid (Glaeser, Kahn and Rappaport 2001). As transit commuting declines in importance for other groups, tendencies toward residential separation will be magnified. If immigrants have lower tastes for suburban amenities, the process of "urban sprawl" may also lead to such separation even in the absence of transit, as immigrant households sort into neighborhoods that have fallen out of favor with natives.

There are two ways of testing this hypothesis. First, if the decline of public transit has increased the segregation of groups that rely on it, controls for public transit use should modify the observed segregation time trend. Second, the formation of immigrant enclaves in neighborhoods undergoing depopulation by natives should lead to a negative association between immigrant segregation and the price immigrants pay for housing. 


\section{Direct Evidence on the Determinants of Segregation}

To understand the factors underlying the rise of immigrant segregation in the latter part of the $20^{\text {th }}$ century, we formed a panel dataset of segregation indices, where the unit of observation is the country of origin/city of residence/year. As Tables $3 \mathrm{a}$ and $3 \mathrm{~b}$ indicate, the resulting dataset has 7,362 observations spanning the years 1910 to 2000 .

In each table, the specification reported in column (1) includes only year effects as explanatory variables, to redisplay the basic time trends first made evident in Figure $1 .{ }^{10}$ Table $3 \mathrm{a}$, which focuses on the dissimilarity index, shows discrete jumps in dissimilarity levels between 1920 and 1940, and again between 1950 and 1970, followed by steady increases through 1990. Average dissimilarity levels were roughly 20 percentage points higher in 2000 than they were in 1910. Some portion of the earlier increases in measured segregation may result from methodological changes put in place between 1920 and 1940 (the switch from ward to tract as a neighborhood unit) and 1950 and 1970 (the switch from city to MSA as a unit of aggregation). ${ }^{11}$ Our previous research (Cutler, Glaeser and Vigdor 1999) suggests that the first switch, in particular, should lead to an increase in measures of segregation. Table $3 b$, however, shows that increased segregation indices are not an inevitable result of these methodological changes. As was evident in Figure 1, Isolation levels declined for several decades after 1910, only to rise significantly after 1970. According to this regression specification, isolation levels in 2000 were virtually indistinguishable from those in 1910.

\footnotetext{
${ }^{10}$ These regressions are weighted by the number of observations used to compute certain immigrant community/year specific characteristics using IPUMS data. This weighting procedure is roughly equivalent to weighting observations by immigrant community size. Thus, the year effects can be interpreted as year-to-year differences in the level of segregation experienced by the typical immigrant.

${ }^{11}$ Note that increases in segregation attributable to the switch from city to MSA reporting between 1950 and 1970 can be thought of as consistent with the urban form hypothesis.
} 
Columns (2) through (5) in both tables introduce an increasing number of covariates to the analysis, with the intention of explaining the time patterns of segregation shown in the first column. Column (2) begins the process by introducing city/metropolitan area fixed effects into the analysis. With these effects in place, the year effects measure within-city changes in segregation levels over time. This alteration actually steepens the slope of the dissimilarity time path: in cities where dissimilarity levels were observed in both 1910 and 2000, the 2000 indices are nearly 28 percentage points higher. The gradual shift of immigrants to less segregated parts of the country has partially masked the overall increase in dissimilarity. Isolation, on the other hand, appears to have declined more rapidly within cities between 1910 and 1970; the 1970 to 2000 trend is roughly equivalent within cities and overall.

The regressions reported in column (3) add a basic set of explanatory variables: the logarithm of city/MSA population, the immigrant group's share of the total population, a measure of the group's average socioeconomic status (SES), and the mean age of immigrant group members in a given city in a given year. ${ }^{12}$ Both dissimilarity and isolation index values tend to be lower for immigrant groups residing in larger cities, though the relationship between population and dissimilarity is not statistically significant. Older immigrant groups also tend to be less segregated by either index measure. There is a significant negative link between SES and isolation levels, but no comparable link appears with dissimilarity. Finally, the impact of group share on segregation, holding other factors constant, differs significantly depending on the segregation index used. Groups forming higher shares of the metropolitan population tend to be both more isolated and less

\footnotetext{
12 The socioeconomic measure is the Occupation Score, which is a measure of average earnings of workers in a given occupation as of 1950. Other measures such as educational attainment and earnings are not available in Census data from 1910 and 1920. The use of age rather than years since immigration reflects the absence of a year of entry variable in some Census enumerations.
} 
dissimilar than other groups. This can be interpreted as a tendency for larger groups to spread out into more neighborhoods while still maintaining high concentrations in a few core areas. This pattern reflects basic information conveyed in Table 1. Only the largest immigrant groups, such as Mexicans in 2000 or Italians in 1910, experience anything above negligible isolation levels. Dissimilarity, on the other hand, is often higher for relatively small groups, such as Vietnamese immigrants in 2000. ${ }^{13}$ As discussed in greater detail below, small groups may need to cluster together at higher rates to take advantage of localized shared resources. Larger groups can maintain critical masses in a larger number of neighborhoods.

Recalling the initial purpose of this exercise, it is quite noteworthy that in both specifications the addition of these four controls, which dramatically improve the models' fit according to $R^{2}$ measures, do nothing to eliminate the pattern of significant year effects that increase over time. If anything, the trend towards higher dissimilarity and isolation is now more striking. The time pattern of isolation appears quite different with these controls. Rather than decrease in the first half of the century and increase thereafter, these results show imply that isolation levels rose dramatically before 1970, and have leveled off since. Comparing Tables $3 a$ and $3 b$, it is apparent that introducing MSA fixed effects and basic control variables makes the time path of the two segregation measures quite similar.

Does the changing composition of the immigrant population explain any portion of the observed increase? In column (4), we introduce a set of four indicators for immigrant groups' country of origin and a set of three indicators for the primary language spoken in the origin country.

\footnotetext{
${ }^{13}$ The average Mexican immigrant community in 2000 had 37,186 residents - more than four times the size of the average Vietnamese immigrant community.
} 
The omitted origin category is European/Canadian, and the omitted language category is English. The results indicate that immigrant groups speaking non-Germanic languages are consistently more segregated from the rest of the population. Immigrants originating in African or Caribbean countries tend to have higher dissimilarity levels; Caribbean immigrants are also more isolated than others. The existence of positive effects for African and Caribbean immigrants suggests that racism, either centralized or decentralized, may play some role in recent increases in immigrant segregation.

Controlling for these categorical variables leads to some reduction in the estimated increase in immigrant segregation over time. The reduction in significant positive year effects between columns (3) and (4) amounts to $40 \%$ in the case of dissimilarity and $25 \%$ for isolation. Thus, some amount of the increases in immigrant segregation observed over the twentieth century can be attributed to increasing linguistic and racial differences between immigrant groups and the general population.

Column (5) controls more thoroughly for differences between immigrant groups, by controlling for a set of group fixed effects. These regression models fit the data particularly well, with $R^{2}$ measures of 0.77 in Table $3 \mathrm{a}$ and 0.83 in Table $3 \mathrm{~b}$. Estimated year effects continue to display an increasing, statistically significant pattern. Intriguingly, the time trend of dissimilarity is actually steeper when controlling for group fixed effects than when controlling for group characteristics. The isolation time trend is flattened somewhat. Thus, by any estimate, there continues to be a significant trend towards increasing immigrant segregation even after controlling for all possible permanent differences between groups originating in different countries, all permanent differences in the characteristics of destination cities, and basic characteristics that vary across groups, cities, and time. 
Could changes in urban form, unrelated to the simple control for population and metropolitan fixed effects used here, explain the rise in segregation over time? One telling clue lies in Table $3 \mathrm{a}$ - the significant jump in dissimilarity between 1950 and 1970, the two years that mark the switch from city- to metropolitan area-level measures of segregation. If the process of suburbanization has increased separation between immigrants and natives, it makes sense that the increase would be invisible so long as the city is the unit of observation.

Table 4 provides more direct evidence on the relationship between changes in urban form and segregation. Specifically, it introduces controls for public transit ridership into the standard regression specifications employed in Tables $3 \mathrm{a}$ and $3 \mathrm{~b}$. Commuting data were collected by the Census Bureau beginning in 1960, thus these models omit city/year observations from before that date. The purpose of introducing these controls is to test the hypothesis that immigrants' reliance on public transportation has reduced their contact with natives, as the latter group moves increasingly toward private automobile transportation as a commuting mode. ${ }^{14}$

The first regression in Table 4 essentially repeats the specification in column (5) of Table 3a, incorporating ethnic group fixed effects but omitting metropolitan area fixed effects. ${ }^{15}$ Coefficient estimates in the two models are highly similar, with the exception that the logarithm of city

\footnotetext{
${ }^{14}$ The share of commuters relying on transportation declined steadily over the latter half of the twentieth century. Between 1990 and 2000, for example, the number of public transit commuters in the United States remained effectively constant, even though the total population grew by $13 \%$.

${ }^{15}$ We omit metropolitan fixed effects in this sample because of the shorter panel length. It should be noted, however, that incorporating metropolitan fixed effects in Table 4's second and fifth regressions switches the sign on the $\log$ (public transit commuters) variable. This result implies that cities where public transit use increases experience declines in immigrant segregation. Such a result could occur if, for example, the marginal users of public transit are natives, and inframarginal users are immigrants. The results in Table 4 are thus driven primarily by crosssectional variation in public transit ridership. Note that the third and sixth regressions in Table 4 cannot be estimated with metropolitan area fixed effects, as those rely exclusively on cross-sectional variation to identify the time-varying impact of public transit ridership.
} 
population exerts a positive and significant impact here but not in the previous table. This discrepancy reflects the use of cross-sectional variation to identify the impact of population. Abstracting from this, it is important to note the continued unexplained significant rise in immigrant segregation between 1970 and 2000.

Introducing a simple control for the logarithm of public transit ridership alters the coefficient estimates in important ways. ${ }^{16}$ First, note that the coefficient on the public transit variable is positive and statistically significant. The inclusion of this variable reduces the magnitude and significance of the coefficient on the logarithm of city population, as well as two of three year effects. Point estimates suggest that the tendency for immigrant segregation to be higher in cities with a high reliance on public transit explains about one-third of the increase in segregation between 1970 and 2000. Point estimates also suggest that higher rates of public transit use explain about half of the positive association between metropolitan area size and segregation.

In relative terms, public transit ridership declined between 1970 and 2000. Thus, the pattern observed in Table 4 is somewhat incongruous with a typical omitted variable story. Transit ridership is positively correlated with segregation, but negatively correlated with the year effects, hence it is difficult to understand why the coefficients in the first regression are "too big." The third regression in Table 4 sheds light on this pattern, by adding interactions between the transit ridership variable and year effects. These interaction terms reveal that the impact of ridership on segregation increased

\footnotetext{
${ }^{16}$ Since these regressions control for the logarithm of city population, controls for the logarithm of public transit ridership are roughly equivalent to controlling for the logarithm of the public transit ridership rate (controlling for the logarithm of individuals working outside the home in each city would make this statement exact). Controlling for public transit ridership share directly yields positive but insignificant coefficients. This pattern implies a decreasing positive impact of public transit usage on segregation. Such a declining impact is wholly consistent with the conjecture offered in the preceding footnote, that immigrants are among the first groups to adopt transit, with natives forming a more marginal group.
} 
significantly over time. In 1970, there was essentially no relationship between public transit ridership and segregation. This correlation first appears in 1990 and continues through 2000. As public transit's market share has decreased, it has become more positively associated with segregation. This pattern makes sense if the commuters switching to other modes are disproportionately likely to be natives, and if changing mode choice is associated with significant changes in location choice.

With interaction terms included, year effects now indicate the time pattern of segregation in metropolitan areas with extremely small levels of public transit ridership. The negative and significant 1990 and 2000 year effects imply that immigrant segregation actually decreased in these areas after 1970. The observed increases in segregation after 1970 occurred primarily in cities with a heavy reliance on transit.

The remaining regression results reported in Table 4 repeat the first set of specifications, using the isolation index in place of dissimilarity. The exact same set of patterns emerges in this case. Introducing the main effect of public transportation usage actually switches the sign of the 1990 and 2000 year effects, and reduces the logarithm of population coefficient substantially. Adding interactions between public transit use and the year effects reveals that transit became an increasingly segregating force over time, and that immigrant segregation tended to fall in metropolitan areas with very little transit usage.

In summary, our analyses of longitudinal variation in immigrant segregation shows that some portion of the increase in immigrant segregation in the latter half of the twentieth century can be attributed to increasing cultural and racial differences between immigrant groups and the native population. A potentially more significant portion, however, can be attributed to changes in urban 
form. Evidence suggests that immigrants have been less than full participants in the trend toward automobile-dependent suburbanization over the past several decades.

\section{Evidence on Housing Prices}

Our theories of immigrant segregation make varying predictions regarding the relationship between immigrant segregation and housing prices. A desire for exposure to one's own culture, or for access to networks that ease the process of assimilation, should lead immigrants to pay a premium for housing in segregated neighborhoods. Immigrants might also pay a premium if natives take collective action to restrict their housing market choice; in earlier work (Cutler, Glaeser and Vigdor 1999) we find evidence of such action directed against blacks in the earlier $20^{\text {th }}$ century. More decentralized nativism may lead to a situation where housing trades at discounted prices in immigrant enclaves, and commands a premium in established native neighborhoods. Such a pattern might also be observed if immigrants tend to congregate in neighborhoods that have fallen into disregard among natives for reasons other than ethnic composition.

Altogether, there are two theories predicting a positive relationship between immigrant segregation and the prices immigrants pay for housing, and two theories predicting a negative relationship. To distinguish between the hypotheses predicting a positive effect, we follow our earlier work (Cutler, Glaeser and Vigdor 1999) and examine the differences in housing premia paid by new and established immigrants, under the assumption that demand for enclave residence is strongest among new migrants, while xenophobia does not discriminate between recent arrivals and others. To distinguish between the hypotheses predicting a negative effect, we test whether the relationship between segregation and housing prices differs for immigrant groups that differ racially 
from the native majority. Finally, we estimate specifications using data from two IPUMS samples, to enable inference regarding the possible contribution these factors make to the increase in immigrant segregation over time.

The results in Table 5a utilize the logarithm of rent as a dependent variable. The unit of observation is a renter-occupied housing unit in any metropolitan area in either 1970 or $2000 .{ }^{17}$ Each regression controls for a set of metropolitan area fixed effects, country of origin fixed effects, and housing structural characteristics, implying that the impact of segregation on rents is identified by comparing the segregation levels of ethnic groups, relative to their national average, within cities. ${ }^{18}$ Segregation indices are set to zero for households headed by native born renters.

In 1970, we find consistent evidence that immigrants paid a premium for housing in segregated areas. A one percentage point increase in dissimilarity is associated with a $0.7 \%$ increase in rent paid by immigrants, controlling for housing quality measures and metro area fixed effects. A percentage point increase in isolation predicts a 1.8 percentage point increase in rents. In the isolation regressions, immigrant group share of the population appears as a significant negative predictor of rent. This result probably relates to the strong positive relationship between group share and isolation, shown in Table $3 \mathrm{~b}$ above. Thus, increases in isolation associated with higher group share do not predict higher housing rents, while increases orthogonal to variation in group share do.

As detailed above, this evidence is consistent either with a decentralized market outcome where immigrants are willing to pay a premium to reside in enclave neighborhoods, or with a market

\footnotetext{
${ }^{17}$ Alternative regression specifications estimated using 1990 Census microdata produce results qualitatively similar to those obtained with 2000 data.

${ }^{18}$ Note that the inclusion of country of origin fixed effects precludes the need to independently control for whether a householder is an immigrant.
} 
featuring artificial barriers to immigrant mobility. To distinguish between these explanations, the second and fourth regressions add controls for whether an immigrant householder arrived in the United States within the past five years, and interacts that indicator with segregation. Recent immigrants tend to pay higher rent overall, but the recent immigrant premium is consistently estimated to be highest when groups experience the least amount of segregation. The evidence is thus more consistent with barriers to residential mobility among immigrants, although demand for enclave residence that increases with time spent in the US could also explain this result.

Identical specifications estimated using 2000 IPUMS data produce noticeably different results. The estimated impact of dissimilarity or isolation on rents continues to be positive, but is never more than one-tenth the magnitude of the 1970 specification. Recent immigrants continue to pay a premium for housing, but evidence of a relationship between this premium and segregation is quite weak. In a period of rapidly rising immigrant segregation, the premium immigrants paid for rental housing in segregated cities largely disappeared.

Table $5 \mathrm{~b}$ shifts attention to owner-occupiers, analyzing variation in self-reported estimates of housing value. In general, the results here replicate the analysis of rent values. Estimates suggest that immigrant owner-occupiers' housing values increased with their group's segregation in 1970. The estimated effects are smaller in magnitude than in the corresponding rent regressions, and fail to attain statistical significance in the case of the isolation index. There is no indication that the value of homes owned by recent immigrants bears any special relationship to segregation.

In 2000, there is statistically significant evidence of a positive relationship between dissimilarity and housing values, but once again the coefficient is one-tenth the magnitude of the equivalent 1970 model. Point estimates for isolation are actually negative and insignificant. Further 
evidence suggests that recently arrived immigrants actually pay a significant discount for owner occupied housing when their group experiences greater segregation. This is consistent either with a pattern of nativism directed predominantly at newly arrived immigrants, or with a tendency for immigrants to purchase housing in neighborhoods where demand is low for reasons other than ethnic composition. It is possible, for example, the value native households associate with neighborhood access to public transportation has declined over time.

Table 6 tests the nativism hypothesis, under the presumption that anti-immigrant sentiment is particularly strong when directed at immigrants with racial backgrounds differing from the majority. The four regressions in this table judge whether immigrants originating in African, Caribbean, or Latin American countries are subject to a greater discount for housing in segregated areas. Such a pattern would be consistent with our earlier finding (Cutler, Glaeser and Vigdor 1999) of a discount in housing prices paid by blacks in segregated cities. Table 6 reveals a small amount of evidence in favor of this hypothesis. Of the twelve displayed interaction terms, exactly one - the interaction of dissimilarity and Caribbean country of origin - is statistically significant and negative. Two other significant interaction terms suggest the reverse of the hypothesis being tested - that immigrants belonging to these minority groups pay a rent premium in metro areas where their group is isolated from the majority.

While not entirely unsupportive of the decentralized nativism hypothesis, this evidence points more clearly to immigrant occupation of less-desirable neighborhoods as a reason for the overall disappearance of the immigrant segregation premium between 1970 and 2000. Our final empirical exercise tests this supposition, making use of the Urban Institute's Underclass Database, which provides longitudinal information on individual neighborhoods, proxied by Census tracts, 
between the 1970 and 2000 Census enumerations. We used this database to compute a dissimilarity index measuring the separation of natives and immigrants in the 2000 Census, and three additional hypothetical dissimilarity indices comparing immigrants' 2000 distribution across tracts to the distribution of natives across tracts in 1970, 1980 and 1990. The hypothetical dissimilarity indices measure the fraction of the immigrant population that would have to switch neighborhoods to identically match the distribution of natives in one of these earlier Census years.

If immigrants disproportionately inhabit neighborhoods that have fallen out of favor among natives, then the dissimilarity between immigrants and the native distribution in earlier Census enumerations should fall below the actual 2000 immigrant-native dissimilarity index. If, on the other hand, immigrants move to newly created neighborhoods at rates similar to those of natives, then suburbanization trends over the past three decades should render current dissimilarity substantially lower than the hypothetical indices.

Figure 10 presents the results of this analysis, classifying metropolitan areas according to whether the distribution of immigrants in 2000 most closely matches the distribution of natives in $1970,1980,1990$ or 2000 . As the figure illustrates, there is some degree of heterogeneity across metro areas, but the most common tendency is for immigrants to occupy neighborhoods more closely associated with past native residence than current native residence. This tendency is most pronounced in the nation's two largest immigrant destinations, New York and Los Angeles, where the current distribution of the immigrant population most closely resembles the 1970 native population. Among the nation's top ten destinations for immigrants, displayed in Figure 10, only in San Diego, Washington, and Miami does the current distribution of immigrants across 
neighborhoods most closely resemble the current distribution of natives. In most areas, immigrant enclaves have appeared in the wake of natives' drive towards the suburban fringe.

\section{Conclusions}

This paper has documented the time series path of segregation for immigrant groups in the United States between 1910 and 2000. These patterns closely track immigration flows to the United States, first declining and then rising after the century's midpoint. Recent increases in immigrant segregation are remarkable for several reasons, not least of which is the fact that they run counter to current trends in racial segregation in American metropolitan areas. Surprisingly, these increases over time do not appear strongly related to increases in the immigrant share of the population, to changes in the average skill level or age of immigrants, or to the evolution of new regions of the country as centers of immigration. Controlling for these factors in many cases increases the slope of the time path of immigrant segregation.

The rise in immigrant segregation appears related to several factors. Newer immigrant groups, particularly those from African or Caribbean nations, are more likely to be racially dissimilar from the American majority. Greater linguistic differences between immigrants' native tongues and English has created a greater demand for enclave communities that offer opportunities to reduce communication costs. Evidence also points to automobile-dependent suburbanization as a segregating force over this time period. Immigrant segregation is more positively associated with public transit usage than it once was; metropolitan areas with little reliance on transit actually witnessed decreases in regression-adjusted segregation over the last three decades of the century. Where transit is a viable transportation alternative, immigrants appear to rely on it much more than the native population. 
Finally, while we have no direct evidence on the time pattern of nativist or xenophobic sentiment, we note that the increase in immigrant segregation after 1970 was accompanied by the disappearance of premiums paid by immigrants for housing in segregated communities. This pattern could be explained either by increasing nativism, or exogenously decreasing tastes for housing in neighborhoods receiving immigrant inflows.

Will immigrant segregation continue its ascent in the twenty-first century? The empirical analysis presented here suggests that future trends in segregation will be determined by the interplay of many forces. The further decentralization of American cities, and the continued shift of immigration flows away from Europe and towards nations with starker linguistic and racial differences from the American majority, point toward increased dissimilarity, particularly for smaller immigrant communities. As immigrant communities grow, however, and as economic convergence continues, the pressures leading to higher segregation levels may be eased, as was evident at least to some extent in the 1990s. Further analysis of the consequences of immigrant isolation, in terms of socioeconomic advancement and cultural assimilation, seems quite prudent in light of these trends. 


\section{References}

Bell, W. (1954) “A Probability Model for the Measurement of Ecological Segregation.” Social Forces v.32 pp.357-64.

Borjas, G. (1995) "Ethnicity, Neighborhoods, and Human Capital Externalities." American Economic Review v.85 pp.365-90.

Comrie, B., S. Matthews and M. Polinsky, eds. (1996) The Atlas of Languages: The Origin and Development of Languages Throughout the World. New York: Quarto, Inc.

Cutler, D.M., E.L. Glaeser and J.L. Vigdor (1999) "The Rise and Decline of the American Ghetto." Journal of Political Economy v.107 pp.455-506.

Denton, N.A. and D.S. Massey (1988) "Residential Segregation of Blacks, Hispanics, and Asians by Socioeconomic Status and Generation.” Social Science Quarterly v.69 pp.797-817.

Duncan, O.D. and B. Duncan (1955) “A Methodological Analysis of Segregation Indexes.” American Sociological Review v.20 pp.210-217.

Duncan, O.D. and S. Lieberson (1959) "Ethnic Segregation and Assimilation." American Journal of Sociology v.64 pp.364-74.

Gans, H.J.(1962) The Urban Villagers: Group and Class in the Life of Italian-Americans. New York: Free Press of Glencoe.

Glaeser, E.L., M.E. Kahn and J. Rappaport (2001) "Why Do the Poor Live in Cities?" National Bureau of Economic Research Working Paper \#7636.

Glaeser, E.L. and J.L. Vigdor (2003) "Racial Segregation: Promising News." in B. Katz and R.E. Lang, eds., Redefining Urban \& Suburban America: Evidence from Census 2000, Volume I. Washington: Brookings Institution Press.

Glazer, N. and D.P. Moynihan (1963) Beyond the Melting Pot: The Negroes, Puerto Ricans, Jews, Italians and Irish of New York City. Cambridge: MIT Press.

Jargowsky, P.A. (2003) "Stunning Progress, Hidden Problems: The Dramatic Decline of Concentrated Poverty in the 1990s." Brookings Institution Policy Brief.

Jargowsky, P.A. (1997) Poverty and Place: Ghettos, Barrios and the American City. New York: Russell Sage.

Kain and Quigley (1975) Housing Markets and Racial Discrimination: A Microeconomic Analysis. New York: Columbia University Press. 
Lazear, E.P. (1999) “Culture and Language” Journal of Political Economy v.107 pp.S95-129

Lieberson, S. (1980) A Piece of the Pie: Blacks and White Immigrants since 1880. Berkeley: University of California Press.

Massey, D. and N. Denton (1988) “The Dimensions of Residential Segregation." Social Forces v.67 pp.281-315.

Taeuber, K.E. and A.F. Taeuber (1965) Negroes in Cities: Residential Segregation and Neighborhood Change. Chicago: Aldine.

Zunz, O. (1982) The Changing Face of Inequality: Urbanization, Industrial Development, and Immigrants in Detroit, 1880-1920. Chicago: University of Chicago Press. 
Table 1: Summary of Dissimilarity and Isolation, 1910-2000

\begin{tabular}{|c|c|c|c|c|c|c|}
\hline \multirow{2}{*}{$\begin{array}{l}\text { Year/Country } \\
\text { of origin }\end{array}$} & \multirow{2}{*}{$\begin{array}{l}\text { Number of } \\
\text { Immigrants }\end{array}$} & \multirow{2}{*}{$\begin{array}{c}\text { Number of } \\
\text { Communities }\end{array}$} & \multicolumn{2}{|c|}{ Dissimilarity } & \multicolumn{2}{|c|}{ Isolation } \\
\hline & & & Mean & Std. Dev. & Mean & Std. Dev. \\
\hline 1910 & $9.3 \mathrm{M}$ & 592 & 0.352 & 0.141 & 0.083 & 0.073 \\
\hline Germany & $1.2 \mathrm{M}$ & 154 & 0.236 & 0.064 & 0.025 & 0.019 \\
\hline Russia & $1.1 \mathrm{M}$ & 90 & 0.501 & 0.065 & 0.124 & 0.041 \\
\hline Ireland & $0.8 \mathrm{M}$ & 69 & 0.240 & 0.061 & 0.020 & 0.009 \\
\hline Italy & $0.7 \mathrm{M}$ & 110 & 0.483 & 0.126 & 0.116 & 0.066 \\
\hline 1920 & $10.9 \mathrm{M}$ & 810 & 0.342 & 0.124 & 0.061 & 0.051 \\
\hline 1940 & $9.0 \mathrm{M}$ & 553 & 0.376 & 0.112 & 0.049 & 0.034 \\
\hline 1950 & $7.6 \mathrm{M}$ & 566 & 0.379 & 0.104 & 0.039 & 0.028 \\
\hline 1970 & $11.6 \mathrm{M}$ & 1,241 & 0.463 & 0.121 & 0.040 & 0.052 \\
\hline 1980 & $10.8 \mathrm{M}$ & 1,309 & 0.513 & 0.132 & 0.051 & 0.067 \\
\hline 1990 & $16.0 \mathrm{M}$ & 2,118 & 0.561 & 0.145 & 0.060 & 0.064 \\
\hline 2000 & $23.4 \mathrm{M}$ & 2,783 & 0.560 & 0.134 & 0.069 & 0.065 \\
\hline Mexico & $7.4 \mathrm{M}$ & 199 & 0.502 & 0.107 & 0.128 & 0.052 \\
\hline Philippines & $1.1 \mathrm{M}$ & 94 & 0.508 & 0.064 & 0.049 & 0.042 \\
\hline Germany & $0.8 \mathrm{M}$ & 174 & 0.358 & 0.068 & 0.005 & 0.004 \\
\hline Vietnam & $0.8 \mathrm{M}$ & 97 & 0.617 & 0.074 & 0.053 & 0.041 \\
\hline India & $0.8 \mathrm{M}$ & 106 & 0.587 & 0.075 & 0.030 & 0.022 \\
\hline China & $0.8 \mathrm{M}$ & 88 & 0.615 & 0.086 & 0.082 & 0.061 \\
\hline
\end{tabular}

Note: Unit of observation for summary statistics is the immigrant community, defined by country of origin and city/MSA. Summary statistics are weighted by the number of immigrants residing in the community. Immigrant communities with less than 1,000 members are excluded from the analysis. 
Table 2: Correlations among alternative computations of segregation indices

\begin{tabular}{|c|c|c|c|c|}
\hline Panel 1: Dissimilarity & $\begin{array}{c}\text { Unweighted } \\
\text { Mean }\end{array}$ & $\begin{array}{l}\text { Correlation } \\
\text { with Original } \\
\text { version }\end{array}$ & $\begin{array}{l}\text { Correlation with } \\
\text { rest. microdata } \\
\text { orig. version }\end{array}$ & $\begin{array}{c}\text { Correlation with } \\
\text { other group = } \\
\text { native version }\end{array}$ \\
\hline Original version & 0.626 & - & - & - \\
\hline $\begin{array}{l}\text { Original version, } \\
\text { computed with } \\
\text { restricted microdata }\end{array}$ & 0.601 & 0.987 & - & - \\
\hline Other group is natives & 0.606 & 0.984 & 0.998 & - \\
\hline $\begin{array}{l}\text { Other group is natives } \\
\text { in native-only } \\
\text { households }\end{array}$ & 0.612 & 0.978 & 0.993 & 0.998 \\
\hline \multicolumn{5}{|l|}{$\begin{array}{l}\text { Panel 2: } \\
\text { Isolation }\end{array}$} \\
\hline Original version & 0.016 & - & - & - \\
\hline $\begin{array}{l}\text { Original version, } \\
\text { computed with } \\
\text { restricted microdata }\end{array}$ & 0.014 & 0.980 & - & - \\
\hline Other group is natives & 0.018 & 0.952 & 0.977 & - \\
\hline $\begin{array}{l}\text { Other group is natives } \\
\text { in native-only } \\
\text { households }\end{array}$ & 0.024 & 0.917 & 0.945 & 0.986 \\
\hline
\end{tabular}


Table 3a: Panel evidence on dissimilarity levels

\begin{tabular}{|c|c|c|c|c|c|}
\hline Independent Variable & (1) & (2) & (3) & (4) & (5) \\
\hline 1920 Year Effect & $\begin{array}{l}-0.006 \\
(0.017)\end{array}$ & $\begin{array}{l}-6.99 * 10^{-4} \\
(0.015)\end{array}$ & $\begin{array}{c}0.001 \\
(0.011)\end{array}$ & $\begin{array}{l}-0.027 \\
(0.018)\end{array}$ & $\begin{array}{l}-0.029^{* *} \\
(0.008)\end{array}$ \\
\hline 1940 Year Effect & $\begin{array}{l}0.070^{* *} \\
(0.018)\end{array}$ & $\begin{array}{l}0.068^{* *} \\
(0.015)\end{array}$ & $\begin{array}{l}0.103^{* *} \\
(0.021)\end{array}$ & $\begin{array}{c}0.040 \\
(0.028)\end{array}$ & $\begin{array}{l}0.050^{* *} \\
(0.013)\end{array}$ \\
\hline 1950 Year Effect & $\begin{array}{l}0.079^{* *} \\
(0.018)\end{array}$ & $\begin{array}{l}0.081^{* *} \\
(0.015)\end{array}$ & $\begin{array}{l}0.131^{* *} \\
(0.019)\end{array}$ & $\begin{array}{c}0.052 \\
(0.032)\end{array}$ & $\begin{array}{l}0.072^{* *} \\
(0.013)\end{array}$ \\
\hline 1970 Year Effect & $\begin{array}{l}0.148^{* *} \\
(0.018)\end{array}$ & $\begin{array}{l}0.184^{* *} \\
(0.015)\end{array}$ & $\begin{array}{l}0.211^{* *} \\
(0.026)\end{array}$ & $\begin{array}{l}0.131^{* *} \\
(0.035)\end{array}$ & $\begin{array}{l}0.174^{* *} \\
(0.019)\end{array}$ \\
\hline 1980 Year Effect & $\begin{array}{l}0.188^{* *} \\
(0.017)\end{array}$ & $\begin{array}{l}0.247^{* *} \\
(0.015)\end{array}$ & $\begin{array}{l}0.248^{* *} \\
(0.023)\end{array}$ & $\begin{array}{l}0.146^{* *} \\
(0.035)\end{array}$ & $\begin{array}{l}0.198^{* *} \\
(0.018)\end{array}$ \\
\hline 1990 Year Effect & $\begin{array}{l}0.208^{* *} \\
(0.015)\end{array}$ & $\begin{array}{l}0.280^{* *} \\
(0.013)\end{array}$ & $\begin{array}{l}0.271^{* *} \\
(0.021)\end{array}$ & $\begin{array}{l}0.169^{* *} \\
(0.033)\end{array}$ & $\begin{array}{l}0.203^{* *} \\
(0.017)\end{array}$ \\
\hline 2000 Year Effect & $\begin{array}{l}0.203^{* *} \\
(0.015)\end{array}$ & $\begin{array}{l}0.275^{* *} \\
(0.013)\end{array}$ & $\begin{array}{l}0.274^{* *} \\
(0.019)\end{array}$ & $\begin{array}{l}0.168^{* *} \\
(0.035)\end{array}$ & $\begin{array}{l}0.199^{* *} \\
(0.016)\end{array}$ \\
\hline Ln(City/MSA Population) & - & - & $\begin{array}{l}-0.006 \\
(0.010)\end{array}$ & $\begin{array}{c}0.004 \\
(0.012)\end{array}$ & $\begin{array}{c}-0.002 \\
(0.008)\end{array}$ \\
\hline Group share & - & - & $\begin{array}{l}-0.764^{* *} \\
(0.302)\end{array}$ & $\begin{array}{l}-0.940^{* *} \\
(0.194)\end{array}$ & $\begin{array}{l}-0.588^{* * *} \\
(0.149)\end{array}$ \\
\hline $\begin{array}{l}\text { Mean occupation score in } \\
\text { group/city/year }\end{array}$ & - & - & $\begin{array}{c}1.30 * 10^{-3} \\
\left(1.22 * 10^{-3}\right)\end{array}$ & $\begin{array}{c}-3.42 * 10^{-4} \\
(0.002)\end{array}$ & $\begin{array}{l}0.002^{* *} \\
(0.001)\end{array}$ \\
\hline $\begin{array}{l}\text { Mean age in } \\
\text { group/city/year }\end{array}$ & - & - & $\begin{array}{c}-0.004^{* *} \\
\left(8.83 * 10^{-4}\right)\end{array}$ & $\begin{array}{l}-0.003^{* *} \\
(0.001)\end{array}$ & $\begin{array}{l}-0.003^{* *} \\
\left(4.04-10^{-4}\right)\end{array}$ \\
\hline African origin country & - & - & - & $\begin{array}{l}0.200^{* *} \\
(0.042)\end{array}$ & - \\
\hline Caribbean origin country & - & - & - & $\begin{array}{l}0.116^{* *} \\
(0.036)\end{array}$ & - \\
\hline Asian origin country & - & - & - & $\begin{array}{c}0.032 \\
(0.035)\end{array}$ & - \\
\hline $\begin{array}{l}\text { Latin American origin } \\
\text { country }\end{array}$ & - & - & - & $\begin{array}{l}-0.003 \\
(0.030)\end{array}$ & - \\
\hline $\begin{array}{l}\text { Germanic language other } \\
\text { than English }\end{array}$ & - & - & - & $\begin{array}{l}-0.014 \\
(0.052)\end{array}$ & - \\
\hline $\begin{array}{l}\text { Indo-European language } \\
\text { other than Germanic }\end{array}$ & - & - & - & $\begin{array}{l}0.125^{* *} \\
(0.033)\end{array}$ & - \\
\hline $\begin{array}{l}\text { Non-Indo-European } \\
\text { language }\end{array}$ & - & - & - & $\begin{array}{l}0.124^{* *} \\
(0.043)\end{array}$ & - \\
\hline City/MSA fixed effects & No & Yes & Yes & Yes & Yes \\
\hline Group fixed effects & No & No & No & No & Yes \\
\hline $\mathrm{N}$ & 7,362 & 7,362 & 7,362 & 7,362 & 7,362 \\
\hline $\mathrm{R}^{2}$ & 0.124 & 0.402 & 0.483 & 0.623 & 0.773 \\
\hline
\end{tabular}

Note: Standard errors in parentheses. Regression specifications are weighted according to the sample size used to compute mean group/city/year characteristics used in columns 3-5. Standard errors in column (4) have been corrected for within-ethnic-group clustering. 
Table 3b: Panel evidence on isolation levels

\begin{tabular}{|c|c|c|c|c|c|}
\hline Independent Variable & (1) & (2) & (3) & (4) & (5) \\
\hline 1920 Year Effect & $\begin{array}{l}-0.018^{* *} \\
(0.008)\end{array}$ & $\begin{array}{l}-0.017^{* *} \\
(0.007)\end{array}$ & $\begin{array}{c}0.009 \\
(0.007)\end{array}$ & $\begin{array}{c}0.004 \\
(0.011)\end{array}$ & $\begin{array}{c}0.001 \\
(0.007)\end{array}$ \\
\hline 1940 Year Effect & $\begin{array}{l}-0.021^{* *} \\
(0.008)\end{array}$ & $\begin{array}{l}-0.023^{* *} \\
(0.007)\end{array}$ & $\begin{array}{l}0.031^{* *} \\
(0.008)\end{array}$ & $\begin{array}{l}0.020^{* *} \\
(0.004)\end{array}$ & $\begin{array}{l}0.018^{* *} \\
(0.008)\end{array}$ \\
\hline 1950 Year Effect & $\begin{array}{l}-0.028^{* *} \\
(0.008)\end{array}$ & $\begin{array}{l}-0.030^{* *} \\
(0.007)\end{array}$ & $\begin{array}{l}0.038^{* *} \\
(0.009)\end{array}$ & $\begin{array}{l}0.025^{* *} \\
(0.012)\end{array}$ & $\begin{array}{l}0.023^{* *} \\
(0.008)\end{array}$ \\
\hline 1970 Year Effect & $\begin{array}{l}-0.029^{* *} \\
(0.008)\end{array}$ & $\begin{array}{l}-0.037^{* *} \\
(0.007)\end{array}$ & $\begin{array}{l}0.061^{* *} \\
(0.013)\end{array}$ & $\begin{array}{l}0.046^{* *} \\
(0.013)\end{array}$ & $\begin{array}{l}0.038^{* *} \\
(0.012)\end{array}$ \\
\hline 1980 Year Effect & $\begin{array}{c}0.005 \\
(0.008)\end{array}$ & $\begin{array}{l}-0.010 \\
(0.007)\end{array}$ & $\begin{array}{l}0.071^{* *} \\
(0.012)\end{array}$ & $\begin{array}{l}0.053^{* *} \\
(0.015)\end{array}$ & $\begin{array}{l}0.043^{* *} \\
(0.012)\end{array}$ \\
\hline 1990 Year Effect & $\begin{array}{c}7.87 * 10^{-4} \\
(0.007)\end{array}$ & $\begin{array}{l}-0.016^{* *} \\
(0.006)\end{array}$ & $\begin{array}{l}0.066^{* *} \\
(0.010)\end{array}$ & $\begin{array}{l}0.048^{* *} \\
(0.014)\end{array}$ & $\begin{array}{l}0.041^{* *} \\
(0.010)\end{array}$ \\
\hline 2000 Year Effect & $\begin{array}{c}0.006 \\
(0.007)\end{array}$ & $\begin{array}{l}-0.005 \\
(0.006)\end{array}$ & $\begin{array}{l}0.073^{* *} \\
(0.012)\end{array}$ & $\begin{array}{l}0.055^{* *} \\
(0.015)\end{array}$ & $\begin{array}{l}0.047^{* *} \\
(0.010)\end{array}$ \\
\hline Ln(City Population) & - & - & $\begin{array}{l}-0.017^{* *} \\
(0.004)\end{array}$ & $\begin{array}{l}-0.014^{* *} \\
(0.007)\end{array}$ & $\begin{array}{l}-0.013^{* *} \\
(0.004)\end{array}$ \\
\hline Group share & - & - & $\begin{array}{l}0.978^{* *} \\
(0.102)\end{array}$ & $\begin{array}{l}0.934^{* *} \\
(0.055)\end{array}$ & $\begin{array}{l}0.772^{* *} \\
(0.108)\end{array}$ \\
\hline Mean occupation score & - & - & $\begin{array}{c}-0.003^{* *} \\
\left(4.68 * 10^{-4}\right)\end{array}$ & $\begin{array}{l}-0.003^{* *} \\
(0.001)\end{array}$ & $\begin{array}{c}-0.003^{* *} \\
\left(3.53 * 10^{-4}\right)\end{array}$ \\
\hline Mean age & - & - & $\begin{array}{l}-0.001^{* *} \\
\left(0.86 * 10^{-4}\right)\end{array}$ & $\begin{array}{c}-0.001^{* *} \\
\left(4.06 * 10^{-4}\right)\end{array}$ & $\begin{array}{l}-0.001^{* *} \\
\left(1.49-10^{-4}\right)\end{array}$ \\
\hline African origin country & - & - & - & $\begin{array}{c}-0.002 \\
(0.008)\end{array}$ & - \\
\hline Caribbean origin country & - & - & - & $\begin{array}{l}0.026^{* *} \\
(0.008)\end{array}$ & - \\
\hline Asian origin country & - & - & - & $\begin{array}{l}0.008 \\
(0.010)\end{array}$ & - \\
\hline $\begin{array}{l}\text { Latin American origin } \\
\text { country }\end{array}$ & - & - & - & $\begin{array}{l}-0.002 \\
(0.010)\end{array}$ & - \\
\hline $\begin{array}{l}\text { Germanic language other } \\
\text { than English }\end{array}$ & - & - & - & $\begin{array}{l}-0.001 \\
(0.003)\end{array}$ & - \\
\hline $\begin{array}{l}\text { Indo-European language } \\
\text { other than Germanic }\end{array}$ & - & - & - & $\begin{array}{l}0.021^{* *} \\
(0.004)\end{array}$ & - \\
\hline $\begin{array}{l}\text { Non-Indo-European } \\
\text { language }\end{array}$ & - & - & - & $\begin{array}{l}0.015^{* *} \\
(0.006)\end{array}$ & - \\
\hline City/MSA fixed effects & No & Yes & Yes & Yes & Yes \\
\hline Group fixed effects & No & No & No & No & Yes \\
\hline $\mathrm{N}$ & 7,362 & 7,362 & 7,362 & 7,362 & 7,362 \\
\hline $\mathrm{R}^{2}$ & 0.021 & 0.271 & 0.767 & 0.789 & 0.833 \\
\hline
\end{tabular}

Note: Standard errors in parentheses. Regression specifications are weighted according to the sample size used to compute mean group/city/year characteristics used in columns 3-5. Standard errors in column (4) have been corrected for within-ethnic-group clustering. 
Table 4: Public transportation and immigrant segregation, 1970-2000

\begin{tabular}{|c|c|c|c|c|c|c|}
\hline \multirow{2}{*}{$\frac{\text { Independent Variable }}{\text { Ln(City Population })}$} & \multicolumn{3}{|c|}{ Dissimilarity } & \multicolumn{3}{|c|}{ Isolation } \\
\hline & $\begin{array}{l}0.029^{* *} \\
(0.004)\end{array}$ & $\begin{array}{l}0.016^{* * *} \\
(0.006)\end{array}$ & $\begin{array}{l}0.011^{*} \\
(0.007)\end{array}$ & $\begin{array}{l}0.014^{* *} \\
(0.003)\end{array}$ & $\begin{array}{c}0.004 \\
(0.004)\end{array}$ & $\begin{array}{c}0.001 \\
(0.004)\end{array}$ \\
\hline Group share & $\begin{array}{l}-1.107^{* *} \\
(0.088)\end{array}$ & $\begin{array}{l}-1.097^{* *} \\
(0.088)\end{array}$ & $\begin{array}{c}-1.092^{* *} \\
(0.087)\end{array}$ & $\begin{array}{l}0.456^{* *} \\
(0.095)\end{array}$ & $\begin{array}{l}0.465^{* *} \\
(0.095)\end{array}$ & $\begin{array}{l}0.467^{* * *} \\
(0.094)\end{array}$ \\
\hline Mean occupation score & $\begin{array}{c}0.002 \\
(0.001)\end{array}$ & $\begin{array}{c}0.002 \\
(0.001)\end{array}$ & $\begin{array}{c}0.002 \\
(0.001)\end{array}$ & $\begin{array}{c}-0.003^{* *} \\
\left(4.99 * 10^{-4}\right)\end{array}$ & $\begin{array}{c}-0.003^{* *} \\
\left(4.94 * 10^{-4}\right)\end{array}$ & $\begin{array}{l}-0.003^{* *} \\
(0.001)\end{array}$ \\
\hline Mean age & $\begin{array}{c}-0.004^{* *} \\
(0.001)\end{array}$ & $\begin{array}{c}-0.004^{* *} \\
\left(4.89 * 10^{-4}\right)\end{array}$ & $\begin{array}{c}-0.004^{* *} \\
\left(4.86^{*} 10^{-4}\right)\end{array}$ & $\begin{array}{c}-0.002^{* *} \\
\left(2.78 * 10^{-4}\right)\end{array}$ & $\begin{array}{c}-0.002^{* *} \\
\left(2.70^{*} 10^{-4}\right)\end{array}$ & $\begin{array}{c}-0.002^{* *} \\
\left(2.69 * 10^{-4}\right)\end{array}$ \\
\hline 1980 Year effect & $\begin{array}{c}0.022^{*} \\
(0.012)\end{array}$ & $\begin{array}{c}0.027^{*} \\
(0.015)\end{array}$ & $\begin{array}{l}-0.012 \\
(0.029)\end{array}$ & $\begin{array}{c}0.002 \\
(0.008)\end{array}$ & $\begin{array}{c}0.006 \\
(0.011)\end{array}$ & $\begin{array}{l}-0.003 \\
(0.024)\end{array}$ \\
\hline 1990 Year effect & $\begin{array}{l}0.030^{* *} \\
(0.011)\end{array}$ & $\begin{array}{c}0.017 \\
(0.014)\end{array}$ & $\begin{array}{l}-0.120^{* *} \\
(0.037)\end{array}$ & $\begin{array}{c}0.001 \\
(0.007)\end{array}$ & $\begin{array}{l}-0.010 \\
(0.009)\end{array}$ & $\begin{array}{l}-0.074^{* *} \\
(0.027)\end{array}$ \\
\hline 2000 Year effect & $\begin{array}{l}0.034^{* *} \\
(0.010)\end{array}$ & $\begin{array}{c}0.022 \\
(0.014)\end{array}$ & $\begin{array}{l}-0.098^{* *} \\
(0.032)\end{array}$ & $\begin{array}{c}0.008 \\
(0.006)\end{array}$ & $\begin{array}{l}-0.002 \\
(0.009)\end{array}$ & $\begin{array}{l}-0.085^{* *} \\
(0.026)\end{array}$ \\
\hline Ln(public transit commuters) & - & $\begin{array}{l}0.008^{* * *} \\
(0.003)\end{array}$ & $\begin{array}{l}-0.001 \\
(0.003)\end{array}$ & - & $\begin{array}{l}0.006^{* *} \\
(0.002)\end{array}$ & $\begin{array}{c}0.001 \\
(0.002)\end{array}$ \\
\hline $\begin{array}{l}\text { Ln(public transit commuters)* } \\
1980 \text { year effect }\end{array}$ & - & - & $\begin{array}{c}0.004 \\
(0.002)\end{array}$ & - & - & $\begin{array}{c}0.001 \\
(0.002)\end{array}$ \\
\hline $\begin{array}{l}\text { Ln(public transit commuters)* } \\
1990 \text { year effect }\end{array}$ & - & - & $\begin{array}{l}0.013^{* *} \\
(0.003)\end{array}$ & - & - & $\begin{array}{l}0.006^{* *} \\
(0.002)\end{array}$ \\
\hline $\begin{array}{l}\text { Ln(public transit commuters)* } \\
2000 \text { year effect }\end{array}$ & - & - & $\begin{array}{l}0.012^{* *} \\
(0.003)\end{array}$ & - & - & $\begin{array}{l}0.008^{* *} \\
(0.002)\end{array}$ \\
\hline Group fixed effects & Yes & Yes & Yes & Yes & Yes & Yes \\
\hline $\mathrm{N}$ & 5,006 & 5,006 & 5,006 & 5,006 & 5,006 & 5,006 \\
\hline $\mathrm{R}^{2}$ & 0.705 & 0.707 & 0.710 & 0.739 & 0.746 & 0.752 \\
\hline
\end{tabular}


Table 5a: Segregation and House Rents

\begin{tabular}{|c|c|c|c|c|c|c|c|c|}
\hline \multirow{4}{*}{$\frac{\text { Independent Variable }}{\text { Segregation }}$} & \multicolumn{8}{|c|}{ Dependent Variable: $\ln$ (Annual Rental Payments) } \\
\hline & \multicolumn{4}{|c|}{1970} & \multicolumn{4}{|c|}{2000} \\
\hline & \multicolumn{2}{|c|}{ Dissimilarity } & \multicolumn{2}{|c|}{ Isolation } & \multicolumn{2}{|c|}{ Dissimilarity } & \multicolumn{2}{|c|}{ Isolation } \\
\hline & $\begin{array}{l}0.732^{* *} \\
(0.124)\end{array}$ & $\begin{array}{l}0.741^{* *} \\
(0.129)\end{array}$ & $\begin{array}{l}1.808^{* * *} \\
(0.464)\end{array}$ & $\begin{array}{l}1.815^{* *} \\
(0.477)\end{array}$ & $\begin{array}{l}0.065^{* *} \\
(0.022)\end{array}$ & $\begin{array}{l}0.049^{* *} \\
(0.024)\end{array}$ & $\begin{array}{c}0.037 \\
(0.175)\end{array}$ & $\begin{array}{c}0.066 \\
(0.176)\end{array}$ \\
\hline Recent Immigrant & - & $\begin{array}{l}0.220^{* *} \\
(0.056)\end{array}$ & - & $\begin{array}{l}0.134^{* *} \\
(0.018)\end{array}$ & - & $\begin{array}{l}0.076^{* *} \\
(0.017)\end{array}$ & - & $\begin{array}{c}0.113 * * \\
(0.011)\end{array}$ \\
\hline Segregation*Recent Immigrant & - & $\begin{array}{l}-0.200^{*} \\
(0.105)\end{array}$ & - & $\begin{array}{l}-0.472^{* *} \\
(0.129)\end{array}$ & - & $\begin{array}{c}0.043 \\
(0.030)\end{array}$ & - & $\begin{array}{c}-0.279 \\
(0.187)\end{array}$ \\
\hline Group Share & $\begin{array}{c}0.433 \\
(0.320)\end{array}$ & $\begin{array}{c}0.366 \\
(0.323)\end{array}$ & $\begin{array}{c}-3.218^{* *} \\
(0.767)\end{array}$ & $\begin{array}{c}-2.910^{* *} \\
(0.747)\end{array}$ & $\begin{array}{c}-0.904^{* *} \\
(0.178)\end{array}$ & $\begin{array}{c}-0.833^{* *} \\
(0.173)\end{array}$ & $\begin{array}{c}-0.895^{* *} \\
(0.222)\end{array}$ & $\begin{array}{l}-0.831 \\
(0.219)\end{array}$ \\
\hline $\mathrm{N}$ & 147,271 & 147,271 & 147,271 & 147,271 & 162,435 & 162,435 & 162,435 & 211,288 \\
\hline $\mathrm{R}^{2}$ & 0.378 & 0.378 & 0.377 & 0.378 & 0.186 & 0.195 & 0.194 & 0.299 \\
\hline
\end{tabular}

Note: Standard errors, corrected for clustering of observations at the MSA by ethnic group level, in parentheses. All specifications control for housing structural characteristics, metropolitan area fixed effects, and country of origin fixed effects.

*** denotes a coefficient significant at the $5 \%$ level, ${ }^{*}$ the $10 \%$ level. 
Table 5b: Segregation and Owner-Occupied House Values

\begin{tabular}{|c|c|c|c|c|c|c|c|c|}
\hline \multirow{4}{*}{$\frac{\text { Independent Variable }}{\text { Segregation }}$} & \multicolumn{8}{|c|}{ Dependent Variable: $\ln ($ Owner's report of housing value $)$} \\
\hline & \multicolumn{4}{|c|}{1970} & \multicolumn{4}{|c|}{2000} \\
\hline & \multicolumn{2}{|c|}{ Dissimilarity } & \multicolumn{2}{|c|}{ Isolation } & \multicolumn{2}{|c|}{ Dissimilarity } & \multicolumn{2}{|c|}{ Isolation } \\
\hline & $\begin{array}{l}0.372^{* *} \\
(0.078)\end{array}$ & $\begin{array}{l}0.371^{* *} \\
(0.079)\end{array}$ & $\begin{array}{c}0.772 \\
(0.520)\end{array}$ & $\begin{array}{c}0.789 \\
(0.518)\end{array}$ & $\begin{array}{c}0.027 \\
(0.017)\end{array}$ & $\begin{array}{l}0.033^{*} \\
(0.017)\end{array}$ & $\begin{array}{l}-0.223 \\
(0.292)\end{array}$ & $\begin{array}{l}-0.183 \\
(0.291)\end{array}$ \\
\hline Recent Immigrant & - & $\begin{array}{l}-0.010 \\
(0.085)\end{array}$ & - & $\begin{array}{c}0.017 \\
(0.027)\end{array}$ & - & $\begin{array}{c}0.042 \\
(0.032)\end{array}$ & - & $\begin{array}{c}0.019 \\
(0.019)\end{array}$ \\
\hline Segregation*Recent Immigrant & - & $\begin{array}{c}0.029 \\
(0.184)\end{array}$ & - & $\begin{array}{l}-0.287 \\
(0.253)\end{array}$ & - & $\begin{array}{l}-0.130^{* *} \\
(0.060)\end{array}$ & - & $\begin{array}{l}-0.740^{* *} \\
(0.185)\end{array}$ \\
\hline Group Share & $\begin{array}{l}0.852^{*} \\
(0.347)\end{array}$ & $\begin{array}{l}0.851^{*} \\
(0.349)\end{array}$ & $\begin{array}{l}-0.810 \\
(0.999)\end{array}$ & $\begin{array}{l}-0.791 \\
(0.992)\end{array}$ & $\begin{array}{l}-0.086 \\
(0.120)\end{array}$ & $\begin{array}{l}-0.093 \\
(0.120)\end{array}$ & $\begin{array}{c}0.097 \\
(0.275)\end{array}$ & $\begin{array}{c}0.080 \\
(0.274)\end{array}$ \\
\hline $\mathrm{N}$ & 188,945 & 188,945 & 188,945 & 188,945 & 289,979 & 289,979 & 289,979 & 289,979 \\
\hline $\mathrm{R}^{2}$ & 0.441 & 0.441 & 0.440 & 0.440 & 0.522 & 0.522 & 0.522 & 0.522 \\
\hline
\end{tabular}

Note: Standard errors, corrected for clustering of observations at the MSA by ethnic group level, in parentheses. All specifications control for housing structural characteristics, metropolitan area fixed effects, and country of origin fixed effects.

** denotes a coefficient significant at the $5 \%$ level, ${ }^{*}$ the $10 \%$ level. 
Table 6: Immigrant race, segregation, and housing prices

\begin{tabular}{lcccc}
\hline & \multicolumn{4}{c}{ Dependent variable: } \\
& $\ln ($ Annual Rental Payments) & $\ln$ (Owner's report of housing value) \\
\cline { 2 - 5 } Independent variable & Dissimilarity & Isolation & Dissimilarity & Isolation \\
\hline Segregation & $0.076^{* *}$ & -0.518 & $0.038^{* *}$ & $-0.785^{* *}$ \\
& $(0.027)$ & $(0.399)$ & $(0.018)$ & $(0.293)$ \\
Segregation*Caribbean & $-0.196^{* *}$ & 0.579 & 0.0001 & $1.054^{* *}$ \\
immigrant & $(0.055)$ & $(0.447)$ & $(0.042)$ & $(0.353)$ \\
Segregation*Latin & 0.052 & $0.840^{*}$ & -0.038 & 0.741 \\
American immigrant & $(0.040)$ & $(0.432)$ & $(0.049)$ & $(0.443)$ \\
Segregation*African & -0.098 & -1.508 & -0.065 & -3.025 \\
immigrant & $(0.055)$ & $(2.061)$ & $(0.052)$ & $(2.541)$ \\
Group share & $-0.893^{* *}$ & $-1.019^{* *}$ & -0.074 & -0.110 \\
& $(0.176)$ & $(0.224)$ & $(0.124)$ & $(0.257)$ \\
& & & & \\
$\mathrm{N}$ & 162,435 & 162,435 & 289,979 & 289,979 \\
$\mathrm{R}^{2}$ & 0.195 & 0.195 & 0.522 & 0.522 \\
\hline
\end{tabular}

Note: Standard errors, corrected for clustering of observations at the MSA by ethnic group level, in parentheses. All specifications control for housing structural characteristics, metropolitan area fixed effects, and country of origin fixed effects.

*** denotes a coefficient significant at the $5 \%$ level, ${ }^{*}$ the $10 \%$ level. 


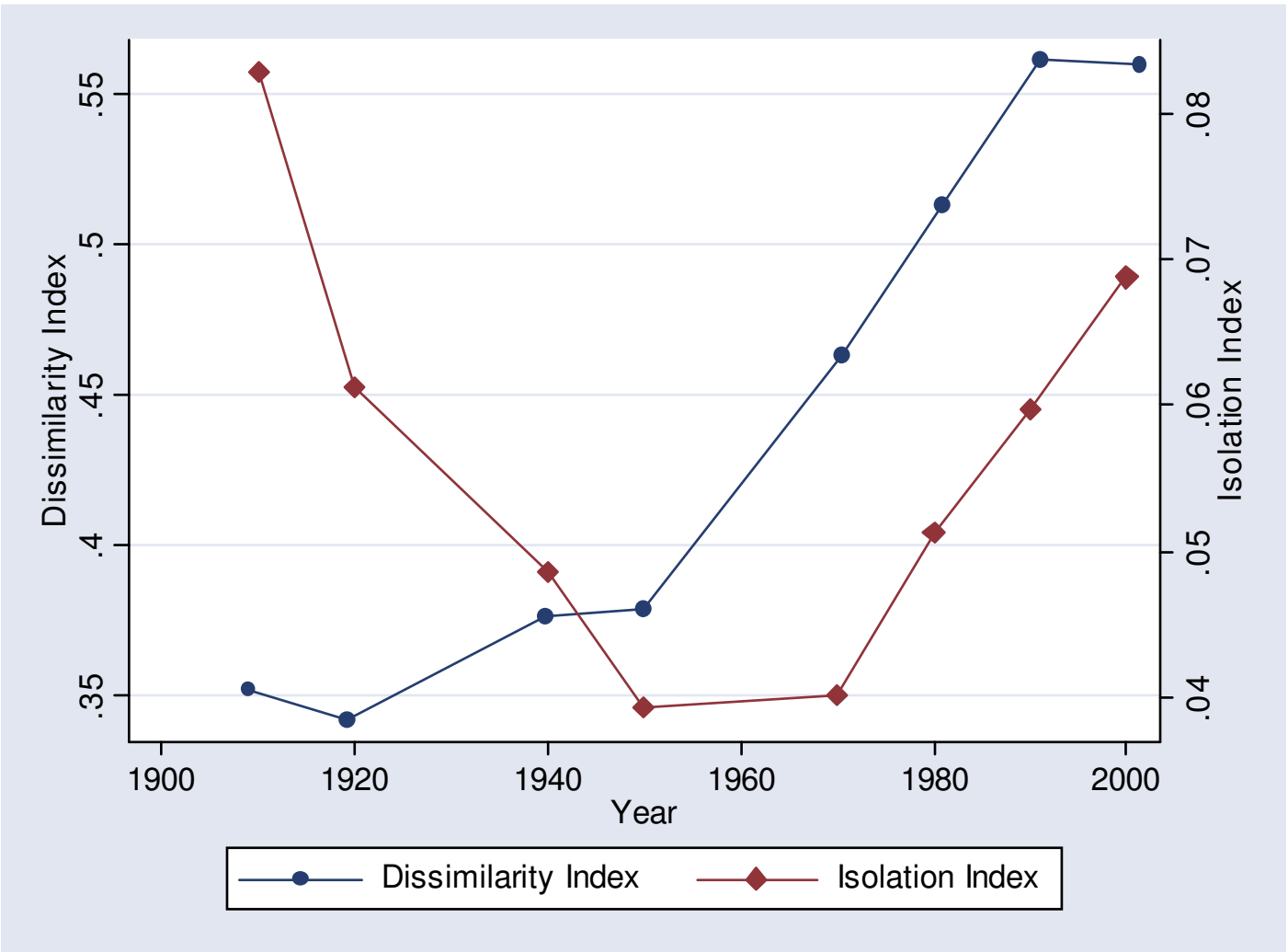

Figure 1: Dissimilarity and Isolation, 1910-2000. Observations are weighted averages of statistics for immigrant communities, with weights equal to the number of immigrants in the community. 


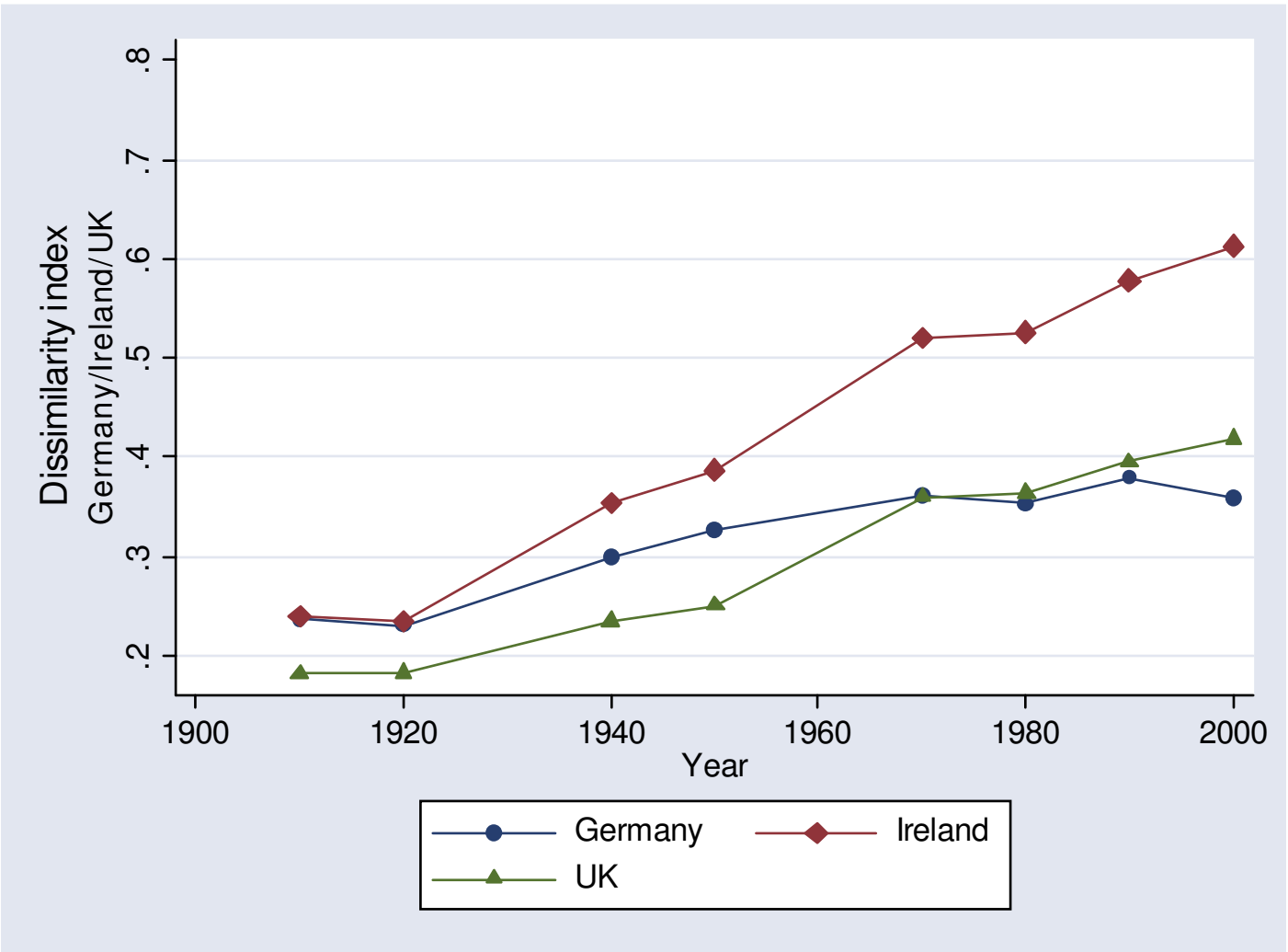

Figure 2: Dissimilarity for older immigrant groups, 1910-2000. Observations are weighted averages of statistics for immigrant communities, with weights equal to the number of immigrants in the community. 


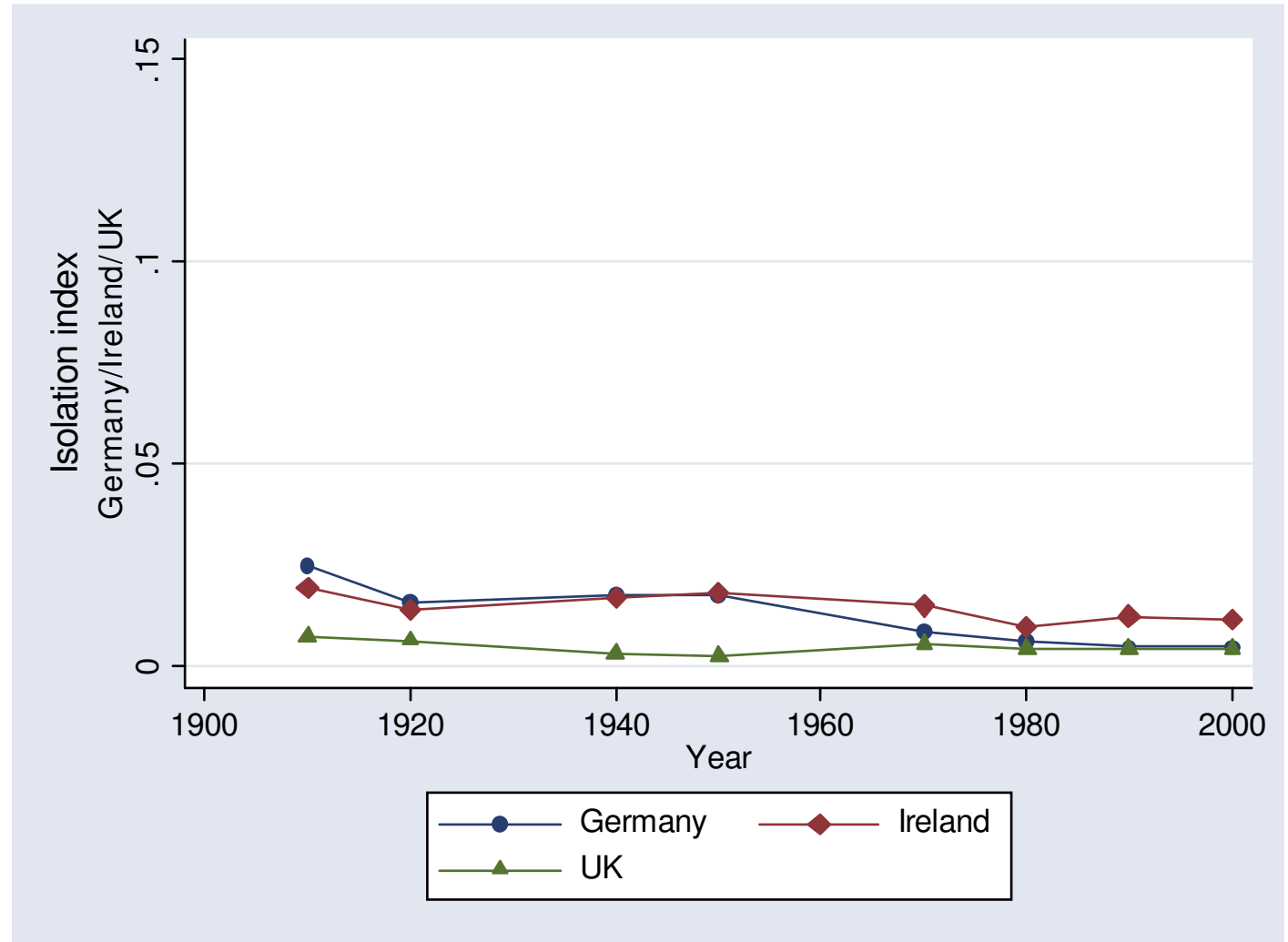

Figure 3: Isolation for older immigrant groups, 1910-2000. Observations are weighted averages of statistics for immigrant communities, with weights equal to the number of immigrants in the community. 


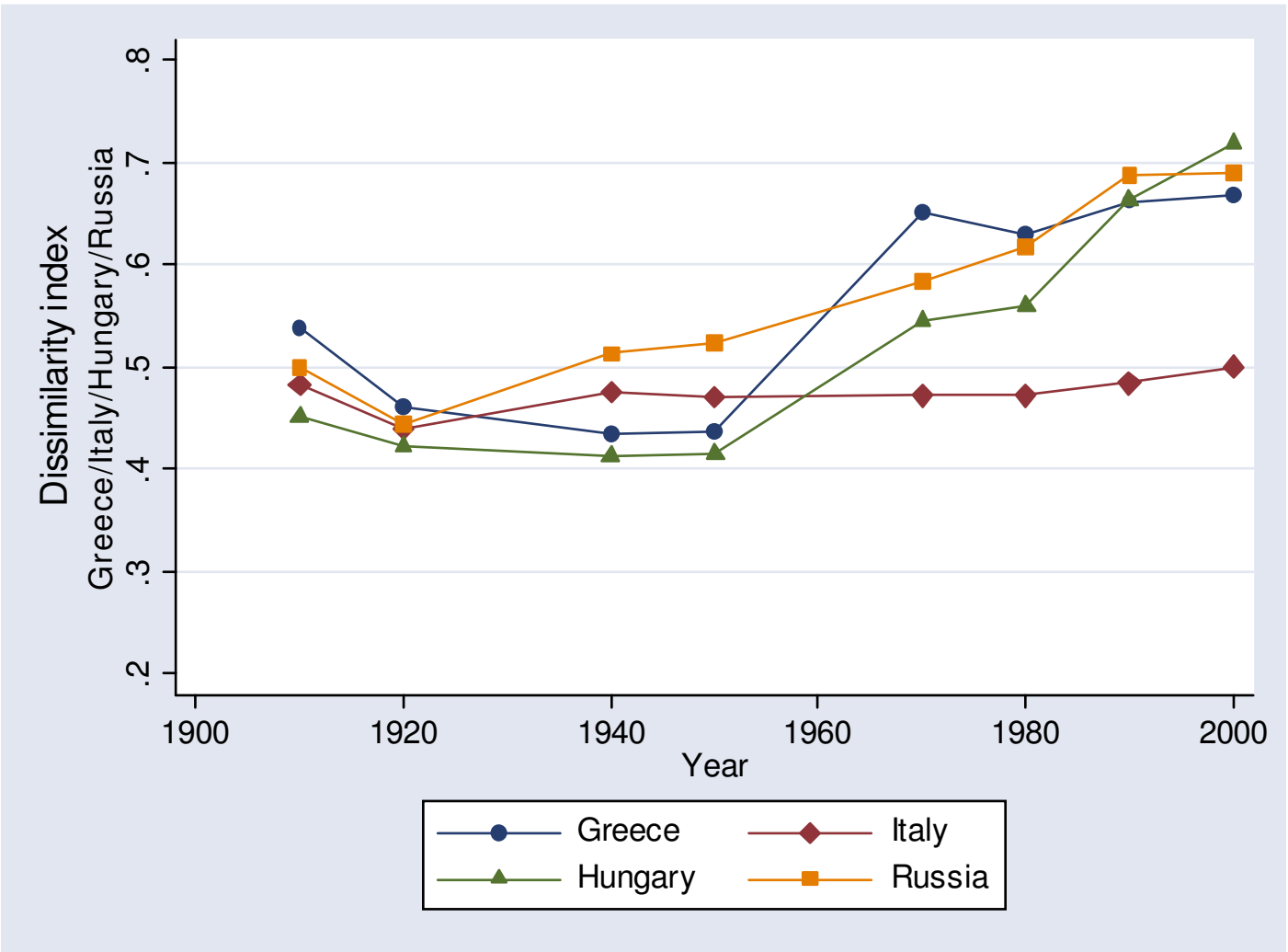

Figure 4: Dissimilarity for new immigrant groups, 1910-2000. Observations are weighted averages of statistics for immigrant communities, with weights equal to the number of immigrants in the community. 


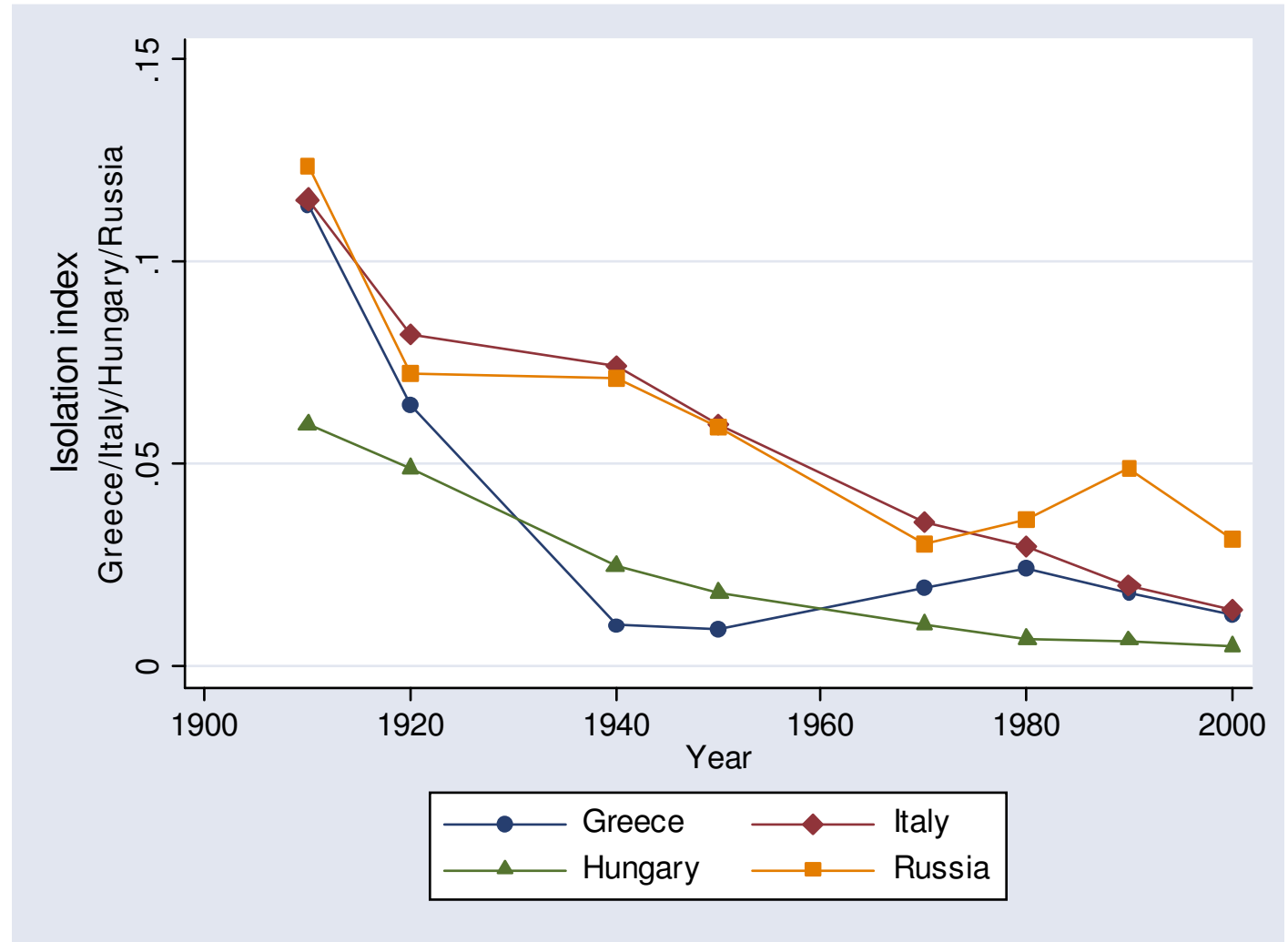

Figure 5: Isolation for new immigrant groups, 1910-2000. Observations are weighted averages of statistics for immigrant communities, with weights equal to the number of immigrants in the community. 


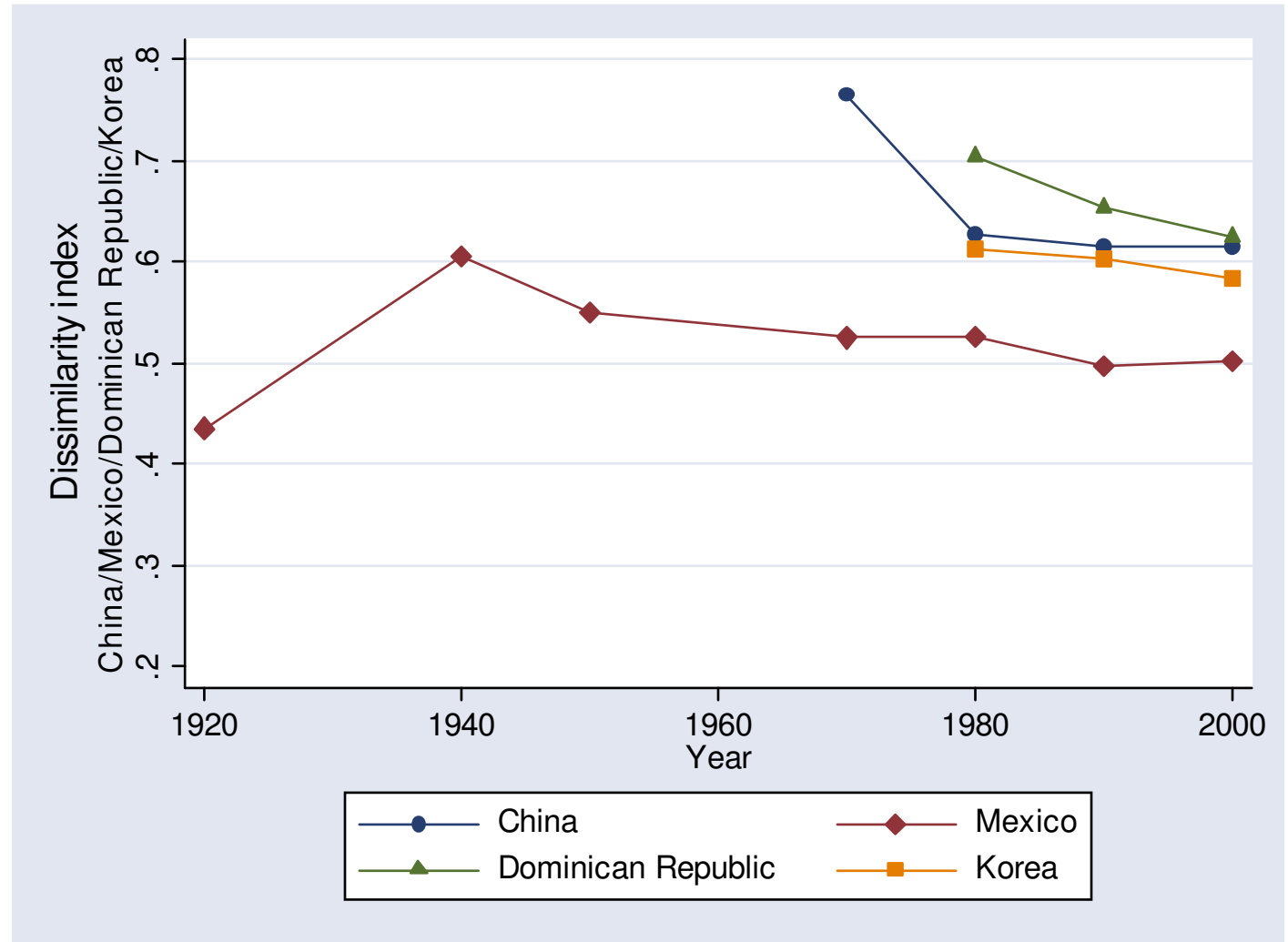

Figure 6: Dissimilarity for newest immigrant groups, 1920-2000. Observations are weighted averages of statistics for immigrant communities, with weights equal to the number of immigrants in the community. 


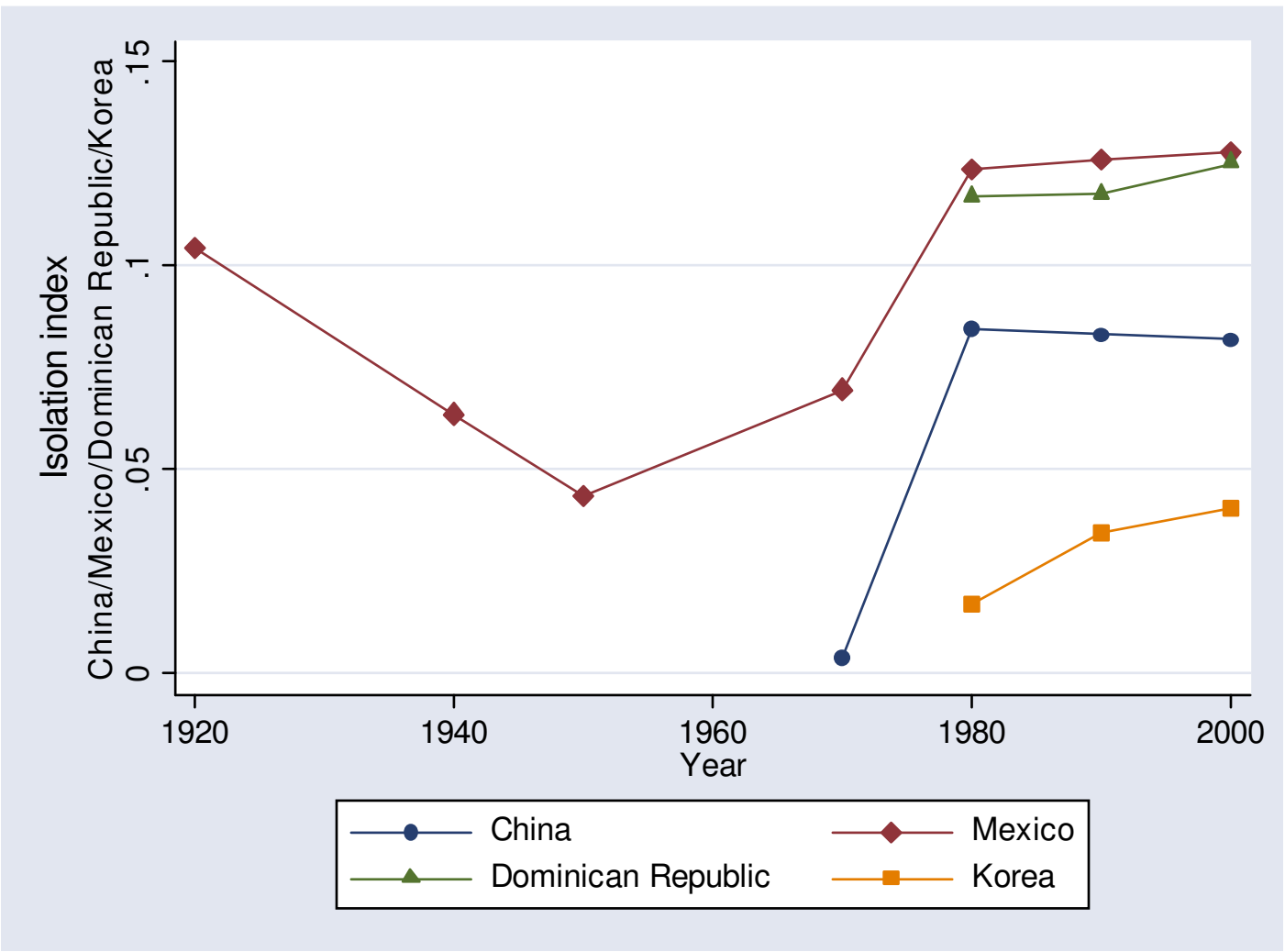

Figure 7: Isolation for newest immigrant groups, 1920-2000. Observations are weighted averages of statistics for immigrant communities, with weights equal to the number of immigrants in the community. 


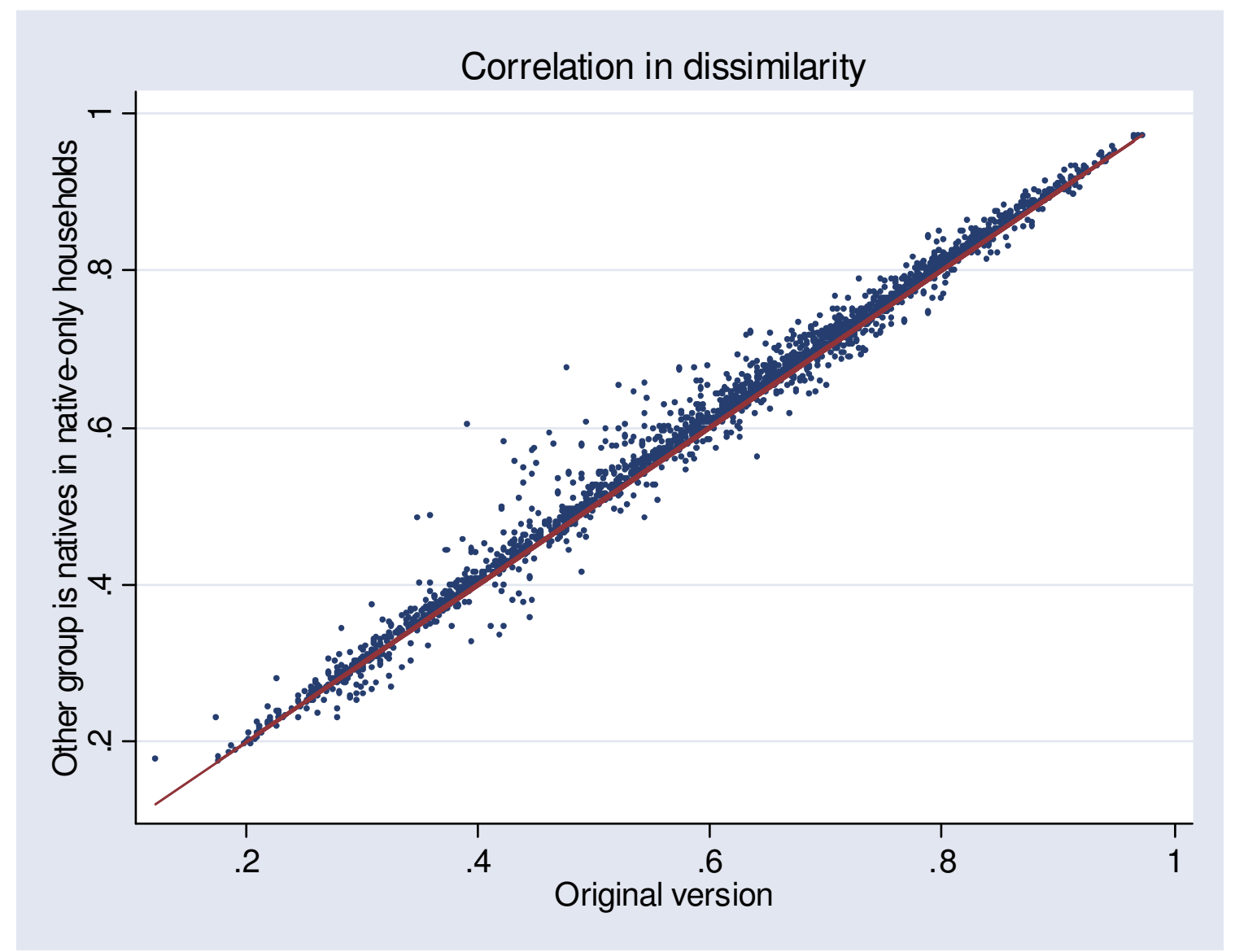

Figure 8: Correlation between original version of dissimilarity index and alternative that compares the distribution of immigrant group members to the distribution of natives living in native-only households. The plotted line is the 45degree line. 


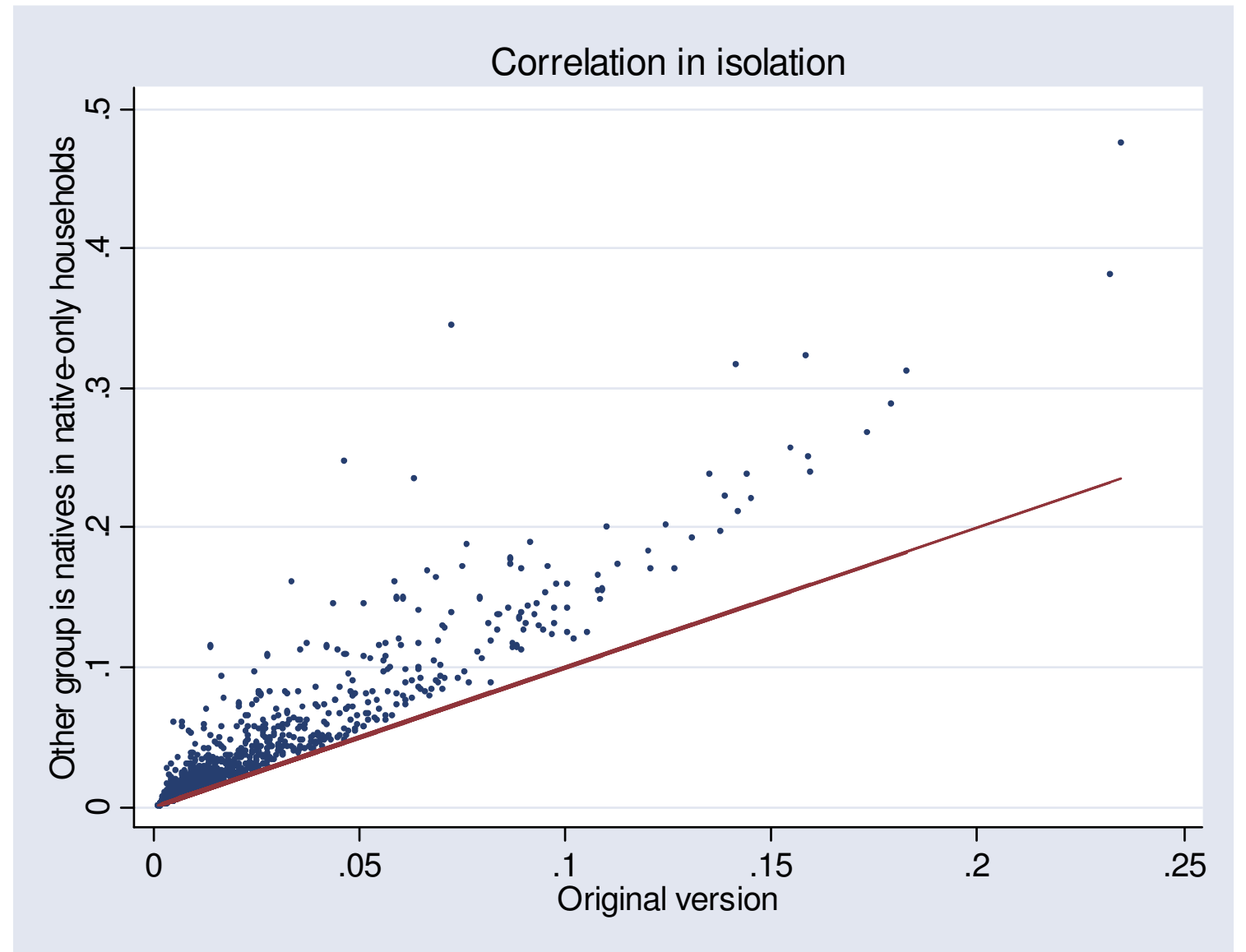

Figure 9: Correlation between original version of isolation index and alternative that compares the distribution of immigrant group members to the distribution of natives living in native-only households. The plotted line is the 45degree line. 
Figure 10: Matching current immigrant locations to past native locations

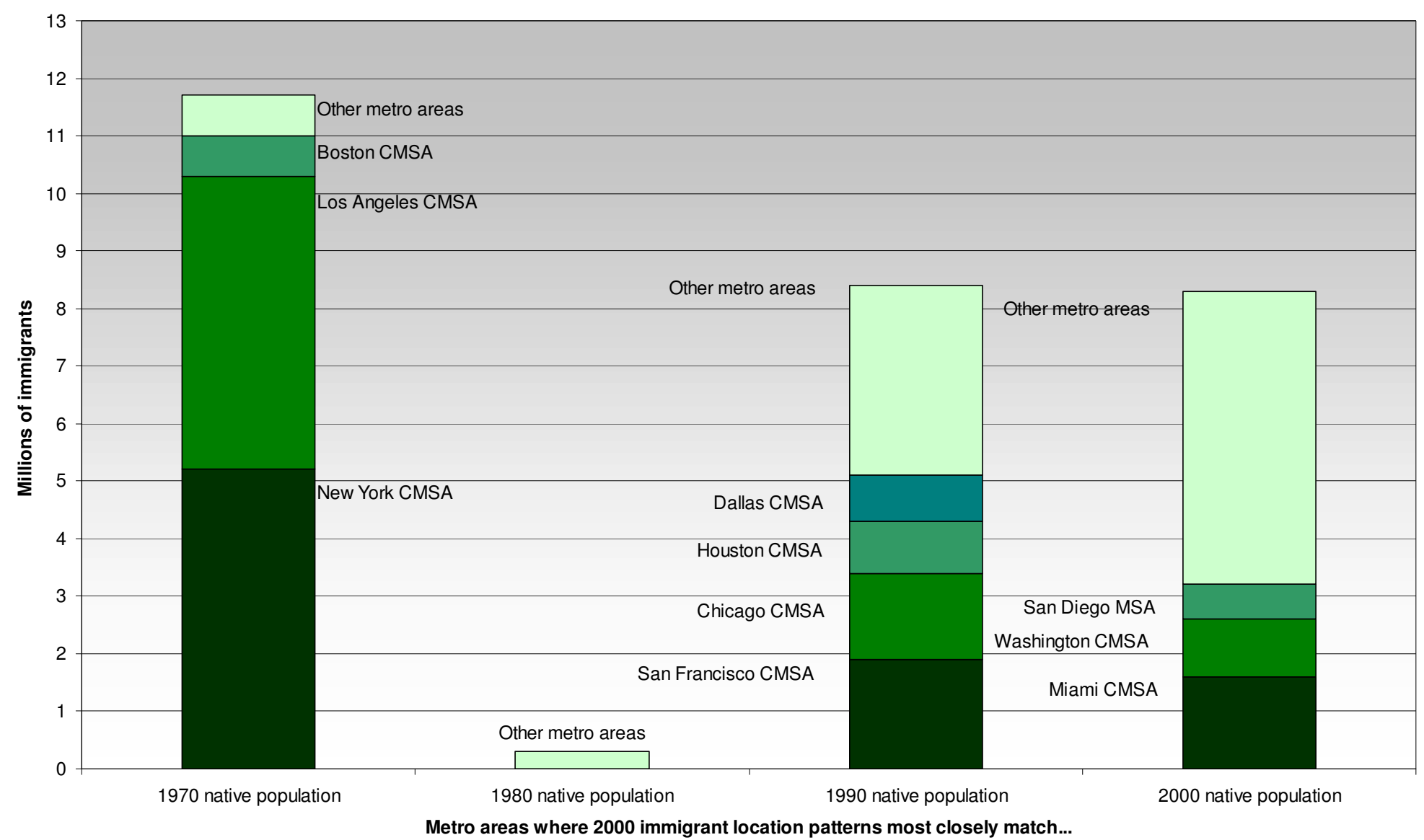

